\title{
Cerebrospinal fluid, antineuronal autoantibody, EEG, and MRI findings from 992 patients with schizophreniform and affective psychosis
}

Dominique Endres $\mathbb{B}^{1,2}$, Sophie Meixensberger ${ }^{1,2}$, Rick Dersch ${ }^{3}$, Bernd Feige $\mathbb{B}^{1,2}$, Oliver Stich ${ }^{3,4}$, Nils Venhoff , Miriam Matysik ${ }^{1,2}$, Simon J. Maier ${ }^{1,2}$, Maike Michel ${ }^{2}$, Kimon Runge ${ }^{1,2}$, Kathrin Nickel ${ }^{1,2}$, Horst Urbach ${ }^{6}$, Katharina Domschke ${ }^{2,7}$, Harald Prüss (10) ${ }^{8,9}$ and Ludger Tebartz van Elst ${ }^{1,2}$

\begin{abstract}
The central role played by cerebrospinal-fluid (CSF) examinations including antineuronal autoantibody (Ab) testing is increasingly recognized in psychiatry. The rationale of this study was to present a multimodally investigated group of patients. In total, 992 patients were analyzed for CSF alterations: 456 patients with schizophreniform and 536 with affective syndromes. Ab measurement included testing for established antineuronal IgG-Abs against intracellular antigens in serum (Yo/Hu/Ri/cv2[CRMP5]/Ma1/Ma2/SOX1/TR[DNER]/Zic4/amphiphysin/GAD65) and for cell surface antigens in the CSF (NMDAR/AMPA-1/2-R/GABA-B-R/LGI1/CASPR2/DPPX). In 30 patients with "red flags" for autoimmune psychosis, "tissue tests" were performed. Additional diagnostics included MRI and EEG analyses. CSF white-blood-cell counts were increased in 4\% and IgG indices in 2\%; CSF-specific oligoclonal bands were detected in 4\%; overall, $8 \%$ displayed signs of neuroinflammation. In addition, 18\% revealed increased albumin quotients. Antineuronal Abs against intracellular antigens were detected in serum in $0.6 \%$. Antineuronal Abs against established cell surface antigens were detected in serum of $1 \%$ and in the CSF of $0.3 \%$ (CSF samples were only questionably positive). Abnormal lgG binding in "tissue tests" was detected in serum of $23 \%$ and in CSF of $27 \%$. In total, $92 \%$ of the Ab-positive patients demonstrated at least one sign of brain involvement in additional diagnostics using CSF, MRI, EEG, and FDG-PET. In summary, CSF basic analyses revealed signs of blood-brain-barrier dysfunction and neuroinflammation in relevant subgroups of patients. Established antineuronal IgG-Abs were rare in serum and even rarer in the CSF. "Tissue tests" revealed frequent occurrences of Ab-binding; therefore, novel antineuronal Abs could play a relevant role in psychiatry.
\end{abstract}

\section{Introduction}

In the last decade, the study of autoimmune encephalitis (AE) and autoimmune psychosis (AP) has rapidly

\footnotetext{
Correspondence: Dominique Endres (dominique.endres@uniklinik-freiburg.de) ${ }^{1}$ Section for Experimental Neuropsychiatry, Department of Psychiatry and Psychotherapy, Medical Center - University of Freiburg, Faculty of Medicine, University of Freiburg, 79104 Freiburg, Germany

${ }^{2}$ Department of Psychiatry and Psychotherapy, Medical Center - University of Freiburg, Faculty of Medicine, University of Freiburg, 79104 Freiburg, Germany Full list of author information is available at the end of the article These authors contributed equally: Dominique Endres and Sophie Meixensberger (shared first authors); Harald Prüss and Ludger Tebartz van Elst (shared last authors)
}

developed $^{1,2}$, largely due to the discovery of anti-N-methylD-aspartate receptor (NMDAR) encephalitis in 2007. Prior to this discovery, patients with suspected $\mathrm{AE}$ were mainly tested for antineuronal autoantibodies (Abs) against intracellular antigens in the context of paraneoplastic processes ${ }^{3}$. Since 2007, however, the importance of AE has increased in the field of psychiatry with the recognition that antiNMDAR encephalitis often manifests with psychotic symptoms and that these patients are usually seen initially by psychiatrists ${ }^{4-7}$. At the same time, several other antineuronal Abs against cell surface antigens (e.g., LGI1) have been discovered that are associated with psychiatric

\section{(c) The Author(s) 2020}

(c) (i) Open Access This article is licensed under a Creative Commons Attribution 4.0 International License, which permits use, sharing, adaptation, distribution and reproduction cc. in any medium or format, as long as you give appropriate credit to the original author(s) and the source, provide a link to the Creative Commons license, and indicate if changes were made. The images or other third party material in this article are included in the article's Creative Commons license, unless indicated otherwise in a credit line to the material. If material is not included in the article's Creative Commons license and your intended use is not permitted by statutory regulation or exceeds the permitted use, you will need to obtain permission directly from the copyright holder. To view a copy of this license, visit http://creativecommons.org/licenses/by/4.0/. 
symptoms. These Abs seem to play a direct pathophysiological role and can occur non-paraneoplastically ${ }^{8}$. The discovery of new Abs is expected in the future; therefore, in this respect, screening examinations using unfixed rodent tissue sections can be helpful for Ab detection ${ }^{9,10}$. Nevertheless, at present, large investigations of the prevalence of antineuronal Abs in patients with psychoses have been limited to unimodal studies using serum ${ }^{11-13}$. Smaller investigations of cerebrospinal fluid (CSF) have revealed antineuronal Abs at significantly lower numbers when compared to serum analyses ${ }^{14,15}$. Multimodal studies that include electroencephalography (EEG), magnetic resonance imaging (MRI), and especially CSF basic analyses with quantification of antineuronal Abs are lacking at present. CSF diagnostics play a central role in the context of antineuronal Abs, since low antigen-specific immunoglobulin (Ig) G Ab titers can be detected even rarely in the serum of healthy individuals ${ }^{11-13}$. This finding emphasizes the necessity of evaluating the pathophysiological relevance of these Abs by CSF analyses, ${ }^{2,16}$. In addition, extended diagnostics using EEG, MRI, or $\left[{ }^{18} \mathrm{~F}\right]$ fluorodeoxyglucose positron emission tomography (FDG-PET) would allow the detection or exclusion of brain involvement in sero-positive patients. According to recently published international consensus criteria for AP, a diagnosis of "probable AP" requires typical CSF, MRI, or EEG findings, while confirmation of a diagnosis of "definite $\mathrm{AP}$ " requires the detection of IgG antineuronal Abs in the $\mathrm{CSF}^{2}$.

\section{Rationale}

At the Department of Psychiatry and Psychotherapy of the University Hospital in Freiburg, patients with schizophreniform syndromes have routinely been offered lumbar punctures (LPs) since approximately June 2009, based on new developments and personal experiences with AEs/ $\mathrm{APs}^{14,17,18}$. The aim of the present study was to conduct a retrospective evaluation of a large cohort of patients with schizophreniform and affective syndromes who underwent multimodal examinations consisting of CSF analyses, antineuronal $\mathrm{Ab}$ testing in serum/CSF, EEG, and MRI.

\section{Patients and methods}

The study received approval from the local ethics committee of the University of Freiburg (EK Fr 396/18). All patients gave written informed consent before LP. Between January 2006 and November 2019, 992 patients were included in the present study.

\section{Patient cohort}

All inpatients with schizophreniform syndromes (according to the International Statistical Classification of Diseases and Related Health Problems criteria, version 10
[ICD-10]: F20.X-F29.X, F06.0-2, F10.5-F19.5) and affective syndromes (unipolar depression following ICD-10: F32.X, F33.X, F06.3 and bipolar disorder following ICD10: F30.X, F31X, F06.3) who underwent an LP at the Department of Psychiatry and Psychotherapy were included. Patients who were transferred to the Department of Neurology for further investigations were not included. Only the first LP results were analyzed for each patient. The patients were clinically diagnosed by experienced senior psychiatrists according to the ICD-10 criteria. For statistical analyses, patients were classified according to their predominant psychiatric syndromes. Patients with schizophreniform or affective syndromes who were also diagnosed with dementia were excluded (ICD-10: F00.X-F04.X). Other preexisting (e.g., earlier stroke) or newly described (e.g., migraine) neurological comorbidities were recorded but not considered as an exclusion criteria if the LP was performed within the diagnostic process of the psychiatric disorder. Since approximately June 2009, patients with schizophreniform syndromes have been offered CSF analysis routinely at our institution, whereas patients with affective syndromes have not been examined routinely. Clinical data were extracted from the patient discharge letters. Some parameters were also taken from the basic clinical documentation, such as the Clinical Global Impression (CGI; ref. ${ }^{19}$ ), Global Assessment of Functioning (GAF; ref. ${ }^{20}$ ), and psychopathological scores following the German Association for Methodology and Documentation in Psychiatry ("AMDP-scores"; ref. ${ }^{21}$ ).

\section{Laboratory methods CSF analyses}

CSF and serum samples were collected simultaneously from all patients ${ }^{22}$. All CSF/serum samples were analyzed in the CSF laboratory of the local department of neurology (https://www.uniklinik-freiburg.de/neurologie/klinik/ diagnostische-einrichtungen/liquor-labor.html). The basic CSF analysis included the determination of white blood cell (WBC) counts (ref.: $<5 / \mu \mathrm{L}$ ), total protein (ref.: $<450 \mathrm{mg} / \mathrm{L}$ ), age-related albumin quotients (AQs; ref.: $<40$ years: $<6.5 \times 10^{-3}$; $40-60$ years: $<8 \times 10^{-3}$; $>60$ years: $<9.3 \times 10^{-3}$ ), IgG indices (ref.: $<0.7$ ), and oligoclonal bands (OCBs) in serum and/or CSF. The OCBs were evaluated as positive if present at $\geq 2$ in CSF with none in the serum ("Wurster type II") or if present at more than 2 in the CSF than in the serum ("Wurster type III"). A correction for WBC counts was made if the WBC count was increased due to blood contamination (correction formula: $1 \mathrm{cell} / \mu \mathrm{L}$ of WBC count reduction per 1000 red blood cells $/ \mu \mathrm{L}$ ). The detailed methodology has been described in previous papers from the working group ${ }^{14,23-26}$. 


\section{Antineuronal antibodies against intracellular and thyroid antigens}

An immunoassay of serum samples has been performed since 2006 at our institution for the detection of antineuronal IgG Abs against intracellular antigens (https:// www.ravo.de/de/Produkte/Line_Assays.php). Initially, Abs against nine antigens were analyzed (Yo, $\mathrm{Hu}, \mathrm{Ri}, \mathrm{Cv} 2 /$ CRMP5, Ma1, Ma2, SOX1, amphiphysin, and GAD65; ravo PNS +2 Blot $\AA$, Freiburg, Germany). Since mid-2014, Abs against TR(DNER) and Zic4 were added (ravo PNS 11 Line Assay®, Freiburg, Germany). Weak bands are questionably positive and rated $(+)$, while clearly positive bands are rated $(+++)$. CSF tests were only performed in selected cases (e.g., in unclear cases with positive serum results). Anti-thyroid Abs against thyroid peroxidase (TPO), thyroglobulin (TG), and thyroid-stimulating hormone receptor (TSHR) were analyzed using electrochemiluminescence immunoassay tests (Roche, Basel, Switzerland).

\section{Antineuronal antibodies against cell surface antigens}

The analysis with fixed biochip assays has been established since 2011 (Euroimmun-kits®, Lübeck, Germany). This initially involved the testing of IgG Abs against five antigens (NMDAR, AMPA-1/2-R, GABA-B-R, LGI1, CASPR2). In 2018, testing for Abs against DPPX was added ("mosaic 6" from Euroimmun ${ }^{\circledR}$; Lübeck, Germany). The tests were initially performed exclusively in the CSF, but since approximately January 2016, both CSF and serum samples have been routinely analyzed. Prior to that date, combined CSF and serum samples were only conducted in particular cases. The Ab findings were divided into questionably positive $(+)$, slightly positive $(+$ + ), and clearly positive $(+++)$. From 2006 to 2011 (and later in special cases), material was sent to the reference laboratory at John Radcliffe Hospital (Prof. Vincent, Oxford, United Kingdom) for anti-NMDAR IgG Abs testing using live cell assays and for anti-VGKC IgG Abs testing using RIAs. The results of these tests are already published $^{14,24}$. For reasons of consistency, the results of the previously published work are listed in the results section; additional unsystematic investigations at Oxford for individual cases are not analyzed here. Testing for Abs associated with demyelinating diseases (AQP4 and MOG) has been established since 2018 on our ward for schizophreniform psychosis using Euroimmun ${ }^{\circledR}$ biochip kits (Lübeck, Germany). Since the end of 2018, tissue-based assays using indirect immunofluorescence on unfixed murine brain tissue were established in patients with "red flags" for AP (e.g., catatonia or CSF specific OCBs) ${ }^{27,28}$ (Prof. Prüss, Charité and DZNE, Berlin, Germany; see exemplary in $\left.{ }^{9}\right)$. Only positive $(+++)$ IgG antibody binding patterns were included in the analysis.

\section{Instrument-based diagnostics EEG}

All patients were offered an EEG examination on admission. The EEGs included a resting-state EEG for approximately ten minutes and (if possible) a hyperventilation (HV) phase for $\sim 3$ min. The EEGs were evaluated by the responsible physicians. In addition, an automated detection of intermittent generalized rhythmic delta/theta activity (IRDAs/IRTAs) was performed. The methodology has been described in the previous papers ${ }^{29,30}$, and the findings were divided into pre-HV-, post $\mathrm{HV}-$, HVdifference (post-HV-pre-HV), and overall-IRDAs/IRTAS.

\section{MRI}

The MRI protocol included at least T1-weighted (axial $5 \mathrm{~mm}$ thick fast spin echo slices on a 1.5 Tesla, MPRAGE sequence with isotropic $1 \mathrm{~mm}^{3}$ voxels on a 3 Tesla scanner), DWI (axial $5 \mathrm{~mm}$ thick slices), and FLAIR sequences (coronal $3 \mathrm{~mm}$ thick fast spin echo slices on a 1.5 Tesla, 3D SPACE sequence with isotropic $1 \mathrm{~mm}^{3}$ voxels on a 3 Tesla scanner). The evaluation was performed by experienced senior physicians in neuroradiology.

\section{Available datasets}

Due to the retrospective approach, not all parameters were available for all patients; moreover, the procedures have been continuously optimized and adapted over the past years. The available datasets are presented in Table 1.

\section{Statistical analyses}

Statistical analysis was performed using the Statistical Package for the Social Sciences, version 24 (IBM Corp., Armonk, NY, USA). The results are largely presented in a descriptive manner. Independent sample $t$-tests were used for the comparison of dimensional variables between the subgroups of patients without age difference. ANCOVA analyses with age correction were used to compare all other dimensional variables (e.g., CSF protein concentration between patients with schizophreniform and affective syndromes) between the subgroups with age difference. Categorical variables (e.g., sex) were compared using $\mathrm{Chi}^{2}$ tests. A binary logistic regression was performed for age-dependent categorical variables (e.g., number of positive OCBs) between different aged groups. Correlations between CSF basic parameters (WBC count, protein, $\mathrm{AQ}$, and IgG index) with EEG-IRDA/IRTA rates, laboratory results (T3/T4, TSH), clinical findings (number of suicide attempts and number of earlier inpatient stays), and psychometric scores (GAF, CGI, AMDP-scores) were analyzed using Spearman correlation. For correlation analyses, all patients were analyzed together. A p-value of $<0.05$ was defined as statistically significant for group comparisons and correlation analyses. Due to the 
Table 1 Overview of the examined parameters and number of patients examined.

\begin{tabular}{ll}
\hline Parameters & $\begin{array}{l}\text { Total } N \text { (Schizophreniform/ } \\
\text { affective syndrome) }\end{array}$ \\
\hline
\end{tabular}

Testing in Serum and CSF

Anti-thyroid antibodies

Established antineuronal lgG antibodies

against different cell surface antigens

Testing for $\lg G$ anti-NMDAR and anti

VGKC- complex antibodies (Prof. Vincent,

Oxford, UK)

"Tissue tests" (Prof. Prüss, Berlin, Germany)

Established antineuronal $\lg G$ antibodies against different intracellular antigens

Established antineuronal $\lg$ G antibodies associated with demyelinating diseases Basic CSF analyses

MRI of the brain
Antigens: TSHR, TPO, TG

Antigens: NMDA-R, AMPA-1/2-R, GABAB-R, LGI1, CASPR2, DPPX

Antigens: NMDA-R, VGKC

Antineuronal Ab testing using indirect immune-fluorescence on unfixed murine brain tissue

Antigens: Yo, Hu, CV2/CRMP5, Ri, Ma1/2, SOX1, GAD65,

amphiphysin, $\operatorname{Tr}^{\mathrm{c}}$, Zic4 ${ }^{\mathrm{c}}$

Antigens: MOG, AQP4

White blood cell count, total protein, albumin quotient, IgG index, OCBs in serum/CSF

Resting state, hyperventilation period

$>$ Classification: Normal, continuous generalized slow activity,

continuous regional slow activity, intermittent generalized slow

activity, intermittent regional slow activity, epileptic pattern

T1/MPRAGE/DWI/FLAIR

$896(418 / 478)$

$>$ Classification: Normal, non-specific white matter changes

(punctuate or patchy and/or confluent), gray matter changes (with special consideration of amygdalae, hippocampi, and other limbic structures), (post-) inflammatory lesions, atrophic changes (global or local), macroangiopathic vascular alterations, microhemorrhages,
954 (449/505), $803(396 / 407)$

Serum: $530(274 / 256)$

Serum: 475 (216/259), CSF: 741 (359/

382)

Serum: $39(29 / 10)^{b}$

Serum and CSF: 30 (16/14)

Serum: $826(405 / 421)$

Serum: $102(67 / 35)$

CSF overall: 992 (456/536);

[WBC: 982 (454/528), protein: 991

(455/536),

AQ: 989 (456/533), IgG Index: 989

(456/533),

OCBs in serum: 965 (449/516), OCB in

CSF: $966(449 / 517)]$

cysts, tumors, anatomical variants, and other changes

CSF cerebrospinal fluid, WBC white blood cell, $A Q$ albumin quotient, $O C B$ oligoclonal bands, IgG immunoglobulin $G, E E G$ electroencephalography, MRI magnetic resonance imaging. $A b$ antibody, $A E$ autoimmune encephalitis, $A M D P$ association for methodology and documentation in psychiatry, AMPA a-amino-3-hydroxy-5methyl-4-isoxazolepropionic acid, ANCOVA analysis of covariance, AP autoimmune psychosis, AQP4 aquaporin-4, BBB blood-brain-barrier, CASPR2 Contactinassociated protein-like 2, CGI clinical global impression, CRMP5 collapsin response mediator protein 5, DNER Delta/Notch-like epidermal growth factor-related receptor, DPPX dipeptidyl-peptidase-like protein-6, FDG-PET $\left[{ }^{18} \mathrm{~F}\right]$ fluorodeoxyglucose positron emissiontomography, FLAIR fluid attenuated inversion recovery, GABA -aminobutyric acid, GAD65 Glutamat-decarboxlase $65 \mathrm{kD}, G A F$ global assessment of functioning, Hu Initials of first patient diagnosed, $H V$ Hyperventilation, ICD International Classification of Diseases, Ig immunglobulin, IgLON5 Iglon family member 5, IRDAs/IRTA Intermittent generalized rhythmic delta/theta activity, LGI1 leucine-rich, glioma inactivated 1, LP lumbar puncture, Ma1 Ma1-protein, Ma2 Ma2-protein, MOG myelin-oligodendrocytes-glycoprotein, MRI magnetic resonance imaging, NMDAR N-methyl-D-aspartate receptor, OCBs oligoclonal bands, PNS paraneoplastic neurological syndromes, Ri Initials of first patient diagnosed, RIA radioimmunoassay, SOX1 Sry-like high mobility group box 1, TG thyroglobulin, TPO thyroid peroxidase, TR[DNER] Delta/Notch-likeEpidermal growth factor-related Receptor, TSHR thyroid-stimulating hormone receptor, VGKC voltage-gated potassium channel, WBC white blood cell, WM white matter, Yo initials of first patient diagnosed, Zic4 Zinc-finger of the cerebellum protein 4.

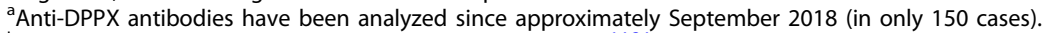

${ }^{\mathrm{b}} \mathrm{Here}$, the authors only describe earlier published findings ${ }^{14,24}$, no rare and unsystematically recorded new findings.

'Anti-Tr- and anti-Zic4-antibodies have been analyzed since approximately August 2015 (in only 453 cases). 
exploratory approach of statistical analyses, no correction was performed for multiple testing.

\section{Results}

\section{Description of the study population}

A total of 992 patients were analyzed. Overall, 456 patients presented with schizophreniform syndromes (46\%) and 536 with affective syndromes (54\%; 455 with unipolar depression and 81 with bipolar disorder). The two subgroups differed significantly in age $(p<0.001)$. The detailed findings are summarized in Tables 2 and 3 . The increase in LPs during the study period is summarized in Fig. 1.

\section{Cerebrospinal fluid basic findings}

WBC counts were increased in $4 \%$ of the patients (range from 1 to $101 / \mu \mathrm{L}: 87 \% \leq 30 / \mu \mathrm{L}, 11 \% \leq 100 / \mu \mathrm{L}, 3 \%>100 /$ $\mu \mathrm{L}$ ), IgG indices were increased in $2 \%$, OCBs were detected in 10\% (in 4\% CSF specific), AQs were elevated in $18 \%$, and protein concentration was elevated in $45 \%$ (range from 107 to $2890 \mathrm{mg} / \mathrm{L}$ ). Therefore, $8 \%$ of the patients discerned signs of neuroinflammation (i.e., increased WBC counts/IgG indices and/or CSF specific OCBs), and $18 \%$ revealed signs of blood-brain-barrier (BBB) dysfunction with increased AQs. Overall, $50 \%$ of the patients displayed some level of CSF alteration (including elevated protein levels). CSF protein levels were more frequently increased in patients with affective disorders (Wald $=5.571, p=0.018$; Table 4).

Patients with pronounced signs of a BBB dysfunction were further analyzed. Thirty percent $(N=7 / 23)$ of the patients with a greatly increased protein concentration of $>1000 \mathrm{mg} / \mathrm{L}$ ( $5 \%$ or $N=23 / 448$ of the patients with increased protein concentrations and $2 \%$ or $N=23 / 991$ of all patients) suffered from schizophreniform and 70\% $(N$ $=16 / 23$ ) from affective syndromes. Comparing the age of patients with protein concentrations $>1000 \mathrm{mg} / \mathrm{L}(N=23$; $\mathrm{M}=50.48 \pm 16.21$ years) and all patients with protein levels $<1000 \mathrm{mg} / \mathrm{L} \quad(N=968 ; \quad \mathrm{M}=42.59 \pm 17.93$ years $)$ highlighted significant differences $(F=1.012, p<0.037)$. When comparing the patients with protein concentrations $>1000 \mathrm{mg} / \mathrm{L}(N=23)$ and all patients with protein levels $<1000 \mathrm{mg} / \mathrm{L}(N=968)$, no significant differences in the rate of EEG (Wald $=1.497, p=0.221$ ) or MRI alterations (Wald $=0.196, p=0.658$ ) were found. In terms of inflammatory CSF alterations (WBC count, IgG Indices, CSF specific OCBs), significant differences (Wald $=9.187, p=0.002$ ) were detected with higher rates in patients with protein concentrations $>1000 \mathrm{mg} / \mathrm{L}$ (26\%; vs. $7 \%$ in patients with protein concentration $<1000 \mathrm{mg} / \mathrm{L}$ ). There were differences in the number of earlier suicide attempts with higher rates in patients with protein concentrations $>1000 \mathrm{mg} / \mathrm{L}$ (64\%) versus patients with protein concentration $<1000 \mathrm{mg} / \mathrm{L}$ ( $35 \%$; Wald $=4.307, p=$ 0.038 ), but no differences in the number of earlier patient instays, and different psychopathological scores (GAF/ AMDP scores). Among the patients with elevated agerelated AQs $(N=174 / 989), 49 \%(N=85 / 174)$ suffered from schizophreniform and 51\% $(N=89 / 174)$ from affective syndromes. Their average age was $42.88( \pm 16.43)$ years. When comparing the patients with elevated AQs and those with normal AQs $(N=815 / 989)$, no differences in the rate of EEG/MRI and inflammatory CSF abnormalities were found. Patients with elevated age-related AQs had higher rates of earlier suicide attempts (in 47\%) compared with patients with normal AQs (34\%; $\mathrm{Chi}^{2}=$ 4.143, $p=0.042$ ).

The group of patients with first-episode schizophreniform syndromes $(N=188)$ showed the following alterations: increased WBC count in $8 / 188$ patients (4\%), elevated AQs in $31 / 188$ patients (16\%), increased protein concentration in 74/187 patients (40\%), increased IgG indices in 4/188 patients (2\%), and CSF-specific OCBs in $11 / 186$ patients (6\%). OCBs in serum and CSF were detected in $8 / 186$ patients (4\%). Patients with first-episode $(\mathrm{M}=32.72$ years, $\mathrm{SD}=15.59, N=188)$ and recurrent/ chronic $(\mathrm{M}=37.07$ years, $\mathrm{SD}=14.14, N=267)$ schizophreniform syndromes differed significantly in age $(F=$ $0.287, p=0.002)$. No significant differences were noted in mean WBC count $(F=0.214, p=0.644)$, protein concentration $(F=0.070, p=0.791)$, AQ $(F<0.001, p=$ $0.990)$, and IgG indices $(F=0.110, p=0.741)$, or rate of CSF-specific OCBs (Wald $=2.099, p=0.147$ ) between patients with first-episode schizophreniform syndromes $(N=188)$ and patients suffering from recurrent/chronic schizophreniform syndromes $(N=267)$.

Patients with $(\mathrm{M}=42.88$ years, $\mathrm{SD}=18.04, N=916)$ and without $(\mathrm{M}=43.00$ years, $\mathrm{SD}=17.09, N=56)$ psychotropic drugs did not differ significantly in age $(F=0.758, p=0.960)$. The BBB dysfunction (increased AQs) showed no statistically significant differences between patients with $(N=164 / 913 ; 18 \%)$ and patients without $(N=10 / 56 ; 18 \%)$ psychotropic drugs $\left(\mathrm{Chi}^{2}=\right.$ $0.000, p=0.984)$.

Schizophreniform patients with $(N=59,13 \%)$ and without $(N=397,87 \%)$ neurological comorbidities did not differ significantly in age $(F=6.254, p=0.226)$ and showed no statistically significant differences regarding signs of $\mathrm{BBB}$ dysfunction (increased $\mathrm{AQs})\left(\mathrm{Chi}^{2}=\right.$ $1.157, p=0.282$ ) or in terms of inflammatory CSF pathologies $\left(\mathrm{Chi}^{2}=1.909 ; \quad p=0.167\right)$. Depressive/ bipolar patients with $(\mathrm{M}=57.01$ years, $\mathrm{SD}=16.70, N$ $=144,27 \%)$ and without $(\mathrm{M}=46.19, \mathrm{SD}=17.41, N=$ 392, 73\%) neurological comorbidities differed significantly in age $(F=1.993, p<0.001)$ also showed no significant differences in terms of signs of $\mathrm{BBB}$ dysfunction (increased AQs; Wald $=1.665, p=0.197$ ) or in the rate of inflammatory CSF changes (Wald= $2.034, p=0.154)$. 
Table 2 Description of the study sample.

\begin{tabular}{|c|c|c|c|c|}
\hline & Total $(N=992)$ & $\begin{array}{l}\text { Schizophreniform syndrome } \\
(N=456)\end{array}$ & $\begin{array}{l}\text { Affective syndrome } \\
(N=536)\end{array}$ & Statistics \\
\hline \multicolumn{5}{|l|}{ Sociodemographic and clinical findings } \\
\hline Sex & $\begin{array}{l}445 \text { male ( } 45 \%): \\
547 \text { female (55\%) }\end{array}$ & $\begin{array}{l}208 \text { male }(46 \%): \\
248 \text { female (54\%) }\end{array}$ & $\begin{array}{l}237 \text { male (44\%): } \\
299 \text { female (56\%) }\end{array}$ & $\begin{array}{l}\mathrm{Chi}^{2}=0.195 \\
p=0.659\end{array}$ \\
\hline Age (range) in years & $42.75 \pm 17.93$ (from 18-90) & $35.30 \pm 14.89$ (from 18 to 90) & $49.10 \pm 17.87$ (from 18-90) & $\begin{array}{l}F=21.110 \\
\boldsymbol{p}<\mathbf{0 . 0 0 1}\end{array}$ \\
\hline Syndrome ${ }^{a}$ & $\begin{array}{l}\text { Schizophrenia spectrum } \\
(N=456)(46 \%) \\
\text { Depressive spectrum } \\
(N=455)(46 \%) \\
\text { Bipolar spectrum } \\
(N=81)(8 \%)\end{array}$ & $\begin{array}{l}\text { Paranoid-hallucinatory: } 238 \text { (52\%) } \\
\text { Hebephrenic: } 16(4 \%) \\
\text { Catatonic: } 10 \text { (2\%) } \\
\text { Delusional disorders: } 25 \text { (5\%) } \\
\text { Schizoaffective: } 122(27 \%) \\
\text { - Depressive: } 89(73 \%) \\
\text { - Manic: } 23(19 \%) \\
\text { - Mixed: } 10(8 \%) \\
\text { Acute polymorphic psychotic: } \\
25(5 \%) \\
\text { Schizotypal: } 3(1 \%) \\
\text { Substance-induced } \\
\text { psychosis: } 7 \text { (2\%) } \\
\text { Coenesthetic: } 3(0.7 \%) \\
\text { Undifferentiated/atypical: } 3(0.7 \%) \\
\text { Prodromal stage: } 4(0.9 \%)\end{array}$ & $\begin{array}{l}\text { Mild episode: } 2(0.5 \%) \\
\text { Moderate episode: } 30(7 \%) \\
\text { Severe episode: } 379(92 \%) \\
\text { - with psychotic symptoms: } \\
76(20 \%) \\
\text { - without psychotic } \\
\text { symptoms: } 297(80 \%) \\
\text { Unknown: } 44(10 \%) \\
\text { Bipolar, currently depressive: } \\
48(59 \%) \\
\text { Bipolar, currently manic: } \\
19(23 \%) \\
\text { Bipolar, currently mixed: } \\
14(17 \%)\end{array}$ & - \\
\hline Clinical course & & & & - \\
\hline First episode & $279(28 \%)$ & $188(41 \%)$ & $91(17 \%)$ & \\
\hline Chronic (>2 years) & $259(26 \%)$ & $122(27 \%)$ & $137(26 \%)$ & \\
\hline Recurrent & $445(45 \%)$ & 145 (32\%) & $300(57 \%)$ & \\
\hline Unknown & 9 & 1 & 8 & \\
\hline \multicolumn{5}{|l|}{ Previous/current comorbid psychiatric disorders } \\
\hline $\begin{array}{l}\text { Neurodevelopmental disorders (ADHD, } \\
\text { autism, tic disorder) }\end{array}$ & $89(9 \%)$ & $4(0.9 \%)$ & $85(16 \%)$ & \\
\hline Personality disorders & $43(4 \%)$ & $1(0.2 \%)$ & $42(8 \%)$ & \\
\hline Substance abuse/dependence & $114(11 \%)$ & $4(0.9 \%)$ & $110(21 \%)$ & \\
\hline Anxiety & $33(3 \%)$ & $0(0 \%)$ & $33(6 \%)$ & \\
\hline OCD & $24(2 \%)$ & $1(0.2 \%)$ & $23(4 \%)$ & \\
\hline PTSD & $18(2 \%)$ & $0(0 \%)$ & $18(3 \%)$ & \\
\hline Cognitive disorders (MCI) & $41(4 \%)$ & $1(0.2 \%)$ & $40(7 \%)$ & \\
\hline Sleep disturbances & $18(2 \%)$ & $1(0.2 \%)$ & $17(3 \%)$ & \\
\hline Eating disorders & $16(2 \%)$ & $1(0.2 \%)$ & $15(3 \%)$ & \\
\hline Somatoform disorder & $32(2 \%)$ & $0(0 \%)$ & $32(6 \%)$ & \\
\hline Others $^{\mathrm{b}}$ & $9(0.9 \%)$ & $1(0.2 \%)$ & $8(1 \%)$ & \\
\hline \multicolumn{5}{|c|}{ Previous/current comorbid neurological disorders } \\
\hline Neurovascular & $24(2 \%)$ & $5(1 \%)$ & $19(4 \%)$ & \\
\hline Demyelinating & $3(0.3 \%)$ & $1(0.2 \%)^{c}$ & $2(0.4 \%)^{d}$ & \\
\hline Extrapyramidal/movement disorders & $16(2 \%)$ & $3(1 \%)$ & $13(2 \%)$ & \\
\hline Infectious & $6(1 \%)$ & $1(0.2 \%)$ & $5(1 \%)$ & \\
\hline Tumors & $3(0.3 \%)$ & $0(0 \%)$ & $3(0.6 \%)$ & \\
\hline Paroxysmal disorders & $19(2 \%)$ & $8(2 \%)$ & $11(2 \%)$ & \\
\hline Traumatic injuries & $23(2 \%)$ & $17(4 \%)$ & $6(1 \%)$ & \\
\hline Polyneuropathy & $20(2 \%)$ & $1(0.2 \%)$ & $19(4 \%)$ & \\
\hline Migraine and other headache & $46(5 \%)$ & $16(4 \%)$ & $30(6 \%)$ & \\
\hline Restless Legs Syndrome & $16(2 \%)$ & $1(0.2 \%)$ & $15(3 \%)$ & \\
\hline Hydrocephalus & $11(1 \%)$ & $3(0.7 \%)$ & $8(1 \%)$ & \\
\hline Others & $22(2 \%)$ & $5(1 \%)$ & $17(4 \%)$ & \\
\hline \multicolumn{5}{|l|}{ Psychopharmacological treatment } \\
\hline Overall psychopharmaco-logical treatment & & & & - \\
\hline Yes & $916(94 \%)$ & $429(96 \%)$ & $487(93 \%)$ & \\
\hline No & $56(6 \%)$ & $20(4 \%)$ & $36(7 \%)$ & \\
\hline Unknown & 20 & 7 & 13 & \\
\hline
\end{tabular}

Antidepressants 
Table 2 continued

\begin{tabular}{llll}
\hline & Total $(\boldsymbol{N}=\mathbf{9 9 2})$ & $\begin{array}{l}\text { Schizophreniform syndrome } \\
(\boldsymbol{N}=\mathbf{4 5 6})\end{array}$ & $\begin{array}{l}\text { Affective syndrome } \\
(\boldsymbol{N}=\mathbf{5 3 6})\end{array}$ \\
\hline Overall & $518(57 \%)$ & $116(27 \%)$ & $402(83 \%)$ \\
Tricyclic & $59(6 \%)$ & $11(3 \%)$ & $48(10 \%)$ \\
SSRI, SNRI, NDRI, NARI & $451(49 \%)$ & $105(24 \%)$ & $346(71 \%)$ \\
MAO inhibitors & $8(0.9 \%)$ & $0(0 \%)$ & $8(2 \%)$ \\
Antipsychotics & & & $259(53 \%)$ \\
Overall & $671(73 \%)$ & $412(96 \%)$ & $60(12 \%)$ \\
"Typical" & $142(16 \%)$ & $82(19 \%)$ & $48(10 \%)$ \\
Low-potency & $100(11 \%)$ & $52(12 \%)$ & $0(0 \%)$ \\
Medium-potency & $0(0 \%)$ & $0(0 \%)$ & $12(2 \%)$ \\
High-potency & $42(5 \%)$ & $30(7 \%)$ & $227(47 \%)$ \\
"Atypical" & $620(68 \%)$ & $393(92 \%)$ & $114(23 \%)$ \\
Mood stabilizers & & & $68(14 \%)$ \\
Lithium & $149(16 \%)$ & $35(8 \%)$ & $71(13 \%)$ \\
Anticonvulsants & $143(16 \%)$ & $75(17 \%)$ & - \\
Benzodiazepines & $146(16 \%)$ & $75(17 \%)$ & $187(38 \%)$ \\
Number of psycho-pharmacological medi- & & & $175(36 \%)$ \\
cation classes per patient & & $191(45 \%)$ & $95(20 \%)$ \\
Same class/only one drug & $378(41 \%)$ & $150(35 \%)$ & $30(6 \%)$ \\
Two drugs & $325(35 \%)$ & $70(16 \%)$ & $0(0 \%)$ \\
Three drugs & $165(18 \%)$ & $15(3 \%)$ & - \\
Four drugs & $45(5 \%)$ & $3(0.7 \%)$ & - \\
Five drugs & $3(0.3 \%)$ & & - \\
\hline
\end{tabular}

$A D H D$ attention deficit hyperactivity disorder, PTSD post-traumatic stress disorder, OCD obsessive-compulsive disorder, $M C I$ mild cognitive impairment, SSRI selectiveserotonin-reuptake-inhibitor, SNRI serotonin-noradrenalin-reuptake-inhibitor, NDRI norepinephrine-dopamine-reuptake-inhibitor, NARI noradrenalin-reuptakeinhibitor, MAO monoamine oxidase.

a If the lumbar puncture was conducted after clinical improvement, patients were attributed to the initial clinical syndrome.

${ }^{b}$ Other psychiatric comorbidity: dissociative disorders; somatoform disorders include somatization disorders, hypochondriac disorders, persistent pain disorders.

${ }^{\mathrm{C}}$ Relapse of multiple sclerosis with pure psychiatric manifestations.

${ }^{d}$ Multiple sclerosis has been initially diagnosed.

Significant $p$-values are marked in bold.

\section{Autoantibody testing}

The detailed Ab findings are summarized in Table 5. Anti-thyroid Abs were detected in $17 \%$ of all patients.

Established antineuronal Abs against cell surface antigens were detected in the serum of six patients (out of 475 patients tested overall [1\%]) and in the CSF of two patients (out of 741 patients tested overall [0.3\%]). The two conspicuous CSF samples were only questionably positive. Positive antineuronal Abs against intracellular antigens in serum were detected in six patients (out of 826 patients tested overall [0.7\%]). In two of these patients, Abs were also detected in the CSF (not systematically analyzed). Overall, 31 of 826 patients showed slight Ab reactivity against intracellular antigens (4\%). One of 102 tested patients was positive for anti-MOG Abs in serum (1\%).

Overall, positive established antineuronal Abs were detected in the serum of 12 patients (1\% of 826 tested patients), and in the CSF of four patients ( $0.5 \%$ of 741 tested patients). However, not every single $\mathrm{Ab}$ was tested in all patients. A tendency was noted for a more frequent presence of serum Abs against cell surface antigens in patients with schizophreniform syndromes $(p=0.061)$.
Tissue tests were performed in 30 patients who showed red flags for AP (mean age: $42.87 \pm 17.71$ years; sex ratio: 14 males and 16 females; eight patients with first-episode schizophreniform syndromes [27\%]; eight patients with recurrent/chronical course of schizophreniform psychosis [27\%], two patients with first-episode affective syndromes [7\%]; 12 patients with recurrent/chronical course of affective syndromes [40\%]). Seven patients (23\%) had positive results in their serum, and eight patients were positive in their CSF (27\%), mostly with predominant IgG binding to cerebellar and/or hippocampal granule cells (for details see Table 5).

Initially, selected samples $(N=39)$ were also examined in the reference laboratory at Oxford. The results have already been published for five positive cases, with low titer anti-VGKC Abs in four patients, and clearly positive anti-NMDAR Abs in one female patient ${ }^{14,24}$.

\section{Instrument-based diagnostics}

The EEG showed abnormalities in $25 \%$ of the patients, most frequently as alterations in the form of IRDAs/ IRTAs (in 17\%). They were significantly more frequent in patients with schizophreniform psychosis $(p>0.01)$. In 
the automated IRDA/IRTA detection, tendencies for different IRDA/IRTA rates after HV $(p=0.075)$, and for the IRDA/IRTA difference $(p=0.066)$, with higher rates in patients with schizophreniform syndromes, were found. MRIs revealed overall changes in $72 \%$ of patients, with the most frequent being non-specific white matter changes (in $42 \%$, including each individual non-specific lesion), in 9\% the MRI findings were compatible with (post-) inflammatory changes. The findings are shown in detail in Table 6.

\section{Description of antineuronal antibody-positive patients}

A total of 24 patients were positive for antineuronal Abs (this includes an anti-NMDAR Ab-positive, older case tested at Oxford; however, weakly positive antiVGKC Ab titers or weak reactivities in the ravo blot ${ }^{\circledR}$ for Abs against intracellular antigens were not considered as positive). This group included significantly more patients with schizophreniform psychoses $(N=$ 18; $\mathrm{Chi}^{2}=6.577, p=0.010$ ). Overall, $58 \%$ of the $\mathrm{Ab}-$ positive patients had CSF alterations (signs of inflammation in 22\%; increased AQs in 21\%), $54 \%$ had MRI signs, and 33\% had EEG abnormalities. In addition, $60 \%$ of the patients examined with FDG-PET $(N=9 / 15)$ displayed abnormalities. In summary, signs of brain involvement were detected in $92 \%$ of the clearly Abpositive cases (one alteration in 33\%, two alterations in $29 \%$, three alterations in $25 \%$, and four alterations in $4 \%)$. The findings in the clearly Ab-positive patients are presented in detail in Table 7 .

The comparison between clearly Ab-positive $(N=24$, $3 \%)$ and all Ab-negative patients $(N=844 ; 97 \%)$ revealed no significant differences in age $(F=1.719, p=0.209)$ or $\operatorname{sex}\left(\mathrm{Chi}^{2}=0.079, p=0.779\right)$. Overall, $58 \%$ of the patients with clearly Ab-positive findings $(N=24)$ showed CSF basic alterations compared to $53 \%$ in Ab-negative patients $\left(\mathrm{Chi}^{2}=0.282, p=0.595\right)$; comparing inflammatory CSF changes yielded a significant difference $\left(\mathrm{Chi}^{2}=6.024\right.$, $p=0.014$ ) between patients with positive Ab findings (22\%) and those with negative findings (8\%). In the rate of EEG abnormalities, Ab-positive patients $(N=8 / 24,33 \%)$ did not differ from Ab-negative patients $(N=203 / 819$, $25 \%)\left(\mathrm{Chi}^{2}=0.908, p=0.341\right)$. MRI diagnostics revealed no significant difference in terms of white/gray matter and atrophic changes $\left(\mathrm{Chi}^{2}=0.119, \quad p=0.730\right)$ between clearly Ab-positive findings $(N=13 / 24,54 \%)$ and $\mathrm{Ab}-$ negative findings $(N=427 / 844,51 \%)$. Comparison between clinical parameters revealed that formal thought disorders were observed more frequently in Ab-positive cases $(F=0.122, \mathrm{p}=0.024)$. No differences were noted in other AMDP scores or in GAF and CGI scores.

Overall, $54 \%(N=13 / 24)$ of patients with clearly Abpositive findings received immunomodulatory treatment. Of these patients, $87 \%(\mathrm{~N}=11 / 13)$ improved with treatment. The treatment attempts in detail are summarized in Table 7.

\section{Correlation analyses}

AQ was significantly correlated with the overall IRDA/ IRTA rates $(r=-0.082, p=0.012 ; N=943)$, and IRDA rates after HV $(r=-0.077, p=0.029 ; N=802)$. AQ was also correlated with CGI score $(r=0.069, p=0.043 ; N=$ 853), number of earlier suicide attempts $(r=0.097, p=$ $0.041, N=443)$, AMDP score for disorientation ( $r=$ 0.097, $p=0.007 ; N=773)$, AMDP score for fears and compulsions $(r=-0.165, p<0.01 ; N=774)$, AMDP score for hallucinations $(r=0.097, p=0.007 ; N=773)$, and AMDP score for ego boundary disturbances $(r=-0.089$, $p=0.014, N=774$ ). CSF protein levels were significantly correlated with overall IRDA rates $(r=-0.074, p=0.023$; $N=945)$ and IRDA rates before HV $(r=-0.073, p=$ $0.025 ; N=945)$. CSF protein concentration was also correlated with the number of earlier suicide attempts $(r=0.111, p=0.020 ; N=444)$, AMDP-score for disorientation $(r=0.071, p=0.048 ; N=776)$, AMDP score for fear and compulsion $(r=-0.151, p<0.01 ; N=777)$, and AMDP score for hallucinations $(r=-0.082, \mathrm{p}=$ $0.023 ; N=776)$. The IgG index was significantly correlated with the difference in IRDA/IRTA rate before and after $\mathrm{HV}(r=0.072, p=0.042, N=802)$.

\section{Discussion}

This study describes the multimodal diagnostic assessment of a large group of patients with schizophreniform and affective psychoses in a naturalistic inpatient setting in a tertiary care hospital. The main CSF results were signs of BBB dysfunction with increased AQs in $18 \%$ and inflammatory CSF alterations in $8 \%$ of all patients. Positive antineuronal IgG Abs against established intracellular antigens were detected in serum in $0.6 \%$ of the patients. Antineuronal IgG Abs against established cell surface antigens were detected in serum of $1 \%$ of the patients and in the CSF of $0.3 \%$ (CSF samples were only questionably positive). However, patterns of novel antineuronal Abs using tissue tests were detected in the serum and/or CSF of $30 \%$ of patients with schizophreniform or affective syndromes and red flags for AP.

The frequent signs of BBB dysfunction in $18 \%$ of all patients are consistent with results from a recent metaanalysis of patients with schizophrenia and affective disorders $^{31}$. The BBB dysfunction significantly correlated with more severe symptoms (as measured by suicide attempts and CGI score) in the present sample. Current knowledge does not clarify whether these changes are primarily involved in the pathophysiology of mental illness or whether they are triggered secondarily by psychotropic drugs $^{32-34}$. However, our data rather suggest that the 
Table 3 Psychometric and clinical data of the study sample.

\begin{tabular}{|c|c|c|c|c|}
\hline & Total $(N=992)$ & Schizophreniform syndrome $(N=456)$ & Affective syndrome $(N=536)$ & Statistics \\
\hline \multicolumn{5}{|l|}{ Clinical information } \\
\hline \multicolumn{4}{|l|}{ Suicide attempts } & \multirow[t]{11}{*}{-} \\
\hline None & $282(64 \%)$ & $103(62 \%)$ & $179(64 \%)$ & \\
\hline One & $108(24 \%)$ & $37(23 \%)$ & $71(25 \%)$ & \\
\hline Two & $30(7 \%)$ & $12(7 \%)$ & $18(6 \%)$ & \\
\hline Three & $9(2 \%)$ & $4(2 \%)$ & $5(2 \%)$ & \\
\hline Four & $4(0.9 \%)$ & $3(2 \%)$ & $1(0.4 \%)$ & \\
\hline Five & $5(1 \%)$ & $3(2 \%)$ & $2(0.7 \%)$ & \\
\hline Six & $2(0.5 \%)$ & $1(0.6 \%)$ & $1(0.4 \%)$ & \\
\hline Seven & $1(0.2 \%)$ & $1(0.6 \%)$ & $0(0 \%)$ & \\
\hline$>$ Seven & $1(0.2 \%)$ & $0(0 \%)$ & $1(0.4 \%)$ & \\
\hline Unclear & 548 & 292 & 256 & \\
\hline \multicolumn{4}{|l|}{ Earlier inpatient stays } & \multirow[t]{9}{*}{-} \\
\hline None & 147 (21\%) & $71(23 \%)$ & $76(19 \%)$ & \\
\hline One & $183(26 \%)$ & $68(22 \%)$ & $115(28 \%)$ & \\
\hline Two & $126(18 \%)$ & $57(19 \%)$ & 69 (17\%) & \\
\hline Three & 89 (12\%) & $38(12 \%)$ & $51(13 \%)$ & \\
\hline Four & $42(6 \%)$ & $15(5 \%)$ & $27(7 \%)$ & \\
\hline Five & $51(7 \%)$ & $17(6 \%)$ & $34(8 \%)$ & \\
\hline$>$ Five & 75 (11\%) & $42(14 \%)$ & $33(8 \%)$ & \\
\hline Unclear & 279 & 148 & 131 & \\
\hline \multicolumn{4}{|l|}{ School education } & \multirow[t]{7}{*}{-} \\
\hline No degree & $14(2 \%)$ & $9(3 \%)$ & $5(1 \%)$ & \\
\hline Low degree & $174(21 \%)$ & $70(20 \%)$ & $104(23 \%)$ & \\
\hline Medium degree & $235(29 \%)$ & $103(29 \%)$ & $132(29 \%)$ & \\
\hline High degree & $384(47 \%)$ & 169 (47\%) & $215(47 \%)$ & \\
\hline Other & $8(1 \%)$ & $5(1 \%)$ & $3(1 \%)$ & \\
\hline Unknown & 177 & 100 & 77 & \\
\hline \multicolumn{4}{|l|}{ Occupation } & \multirow[t]{9}{*}{-} \\
\hline Employed & 266 (32\%) & $96(28 \%)$ & $170(34 \%)$ & \\
\hline House-wife/-husband & $28(3 \%)$ & $13(4 \%)$ & $15(3 \%)$ & \\
\hline Unemployed & $126(15 \%)$ & $61(18 \%)$ & $65(13 \%)$ & \\
\hline Disability pension & $101(12 \%)$ & $41(12 \%)$ & $60(12 \%)$ & \\
\hline Retirement pension & $133(16 \%)$ & $13(4 \%)$ & $120(24 \%)$ & \\
\hline In-training/in studies/retraining & 149 (18\%) & $98(29 \%)$ & $51(10 \%)$ & \\
\hline Others & $28(3 \%)$ & $16(5 \%)$ & $12(2 \%)$ & \\
\hline Unknown & 161 & 118 & 43 & \\
\hline \multicolumn{5}{|l|}{ Psychometric scores } \\
\hline GAF & $44.08 \pm 69.78$ & $47.92 \pm 106.95$ & $41.36 \pm 14.29$ & $F=8.050$ \\
\hline
\end{tabular}


Table 3 continued

\begin{tabular}{|c|c|c|c|c|}
\hline & Total $(N=992)$ & Schizophreniform syndrome $(N=456)$ & Affective syndrome $(N=536)$ & Statistics \\
\hline Unknown & 185 & 121 & 64 & $p=0.189$ \\
\hline CGl & & & & - \\
\hline Borderline ill & $5(1 \%)$ & $5(1 \%)$ & $0(0 \%)$ & \\
\hline Mildly ill & $28(3 \%)$ & $26(7 \%)$ & $2(0.4 \%)$ & \\
\hline Moderately ill & $113(13 \%)$ & $83(22 \%)$ & $30(6 \%)$ & \\
\hline Markedly ill & $181(21 \%)$ & $64(17 \%)$ & $117(22 \%)$ & \\
\hline Severely ill & 477 (56\%) & $169(46 \%)$ & $308(24 \%)$ & \\
\hline Extreme severely ill & $50(6 \%)$ & $24(6 \%)$ & $26(5 \%)$ & \\
\hline Unknown & 138 & 86 & 50 & \\
\hline
\end{tabular}

GAF global assessment of functioning, CGI clinical global impression.

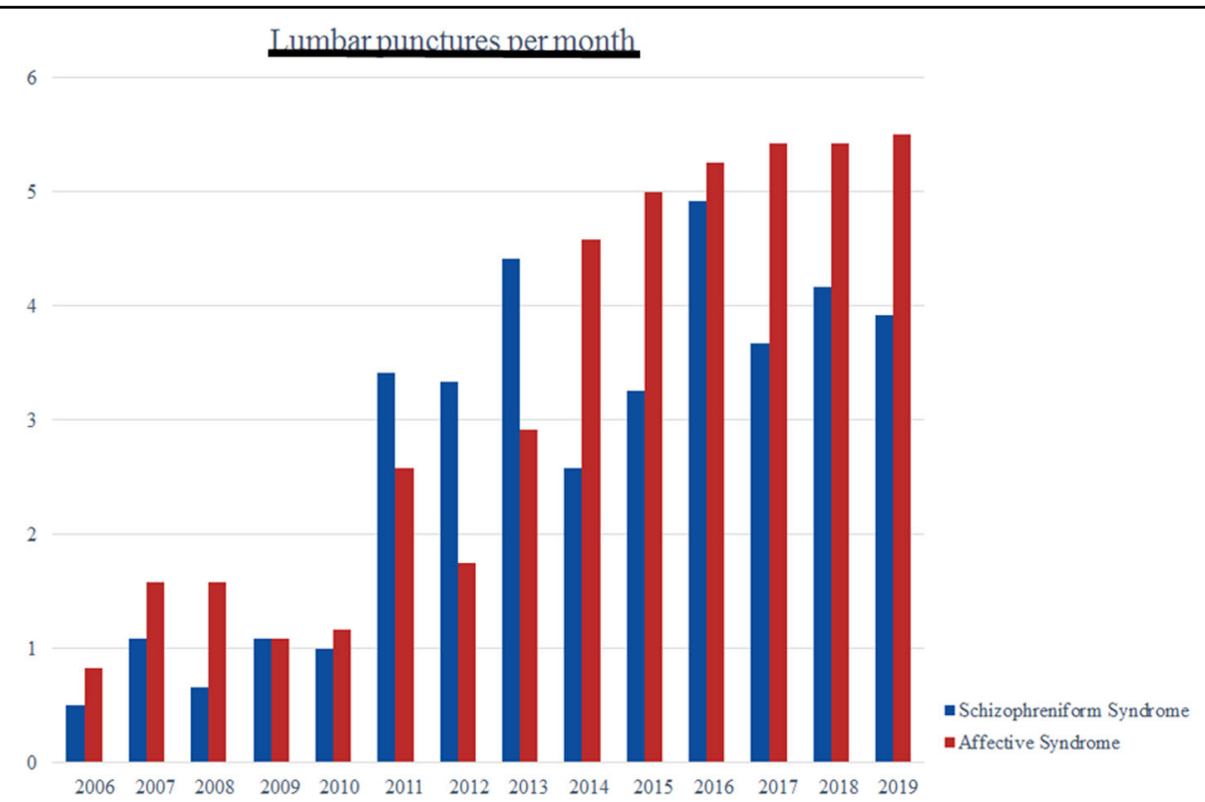

Fig. 1 Average number of lumbar punctures per month over the years. If patients have been treated several times as inpatients or have had repeated lumbar punctures, only the first lumbar puncture appears here.

findings are not caused by medication, since the results did not differ significantly between patients with and without psychotropic drug administration. Irrespective of the cause, a disturbance in $\mathrm{BBB}$ function can induce a harmful interaction between the innate brain and adaptive peripheral immunity ${ }^{35}$. This, in turn, allows the transfer of antineuronal Abs (e.g., against NMDAR) from the serum to the CSF, thereby leading to anti-brain effects ${ }^{36}$.

Inflammatory changes that included mild pleocytosis, elevated IgG indices, or CSF specific OCBs were also detected in a relevant, subgroup (8\%) of all patients. CSF pleocytosis was usually only subtly pronounced (in $87 \%$ from 5 to $30 / \mu \mathrm{L}$ ); therefore, higher cell counts can be assumed to lead to a fulminant disorder and these patients are not treated on psychiatric wards. With regard to the $8 \%$ of patients who showed schizophreniform syndromes with inflammatory changes, the lower prevalence figure compared to some preliminary studies ${ }^{14,15,23,24,37}$ may reflect the screening approach, which has led to an increasing number of patients undergoing LPs over the last few years (see Fig. 1). These inflammatory changes are compatible with pathogen-related pathologies, but they would also be typical for an AE/AP. Both AEs and APs are associated with slightly increased WBC counts or increased IgG indices/CSF specific OCBs ${ }^{1,2,6,16}$.

Antineuronal Ab-associated AEs have recently been described mostly in association with schizophreniform symptomatology ${ }^{2}$. In fact, in the present study samples as 
Table 4 Cerebrospinal fluid findings.

\begin{tabular}{|c|c|c|c|c|}
\hline & Total $(N=992)$ & $\begin{array}{l}\text { Schizophreniform syndromes } \\
(N=456)\end{array}$ & $\begin{array}{l}\text { Affective syndromes } \\
(N=536)\end{array}$ & Statistics \\
\hline \multicolumn{5}{|l|}{ Cerebrospinal fluid basic parameters } \\
\hline WBC counts (Mean $\pm S D$, range) & $\begin{array}{l}1.97 \pm 4.85 \text { (from } 1 \text { to } \\
101 / \mu l)\end{array}$ & $2.11 \pm 6.46$ & $1.84 \pm 2.81$ & $\begin{array}{l}F=0.228 \\
p=0.633\end{array}$ \\
\hline Increased WBC counts (ref. $<5 / \mu \mathrm{l}$ ) & $\begin{array}{l}\uparrow: 38(4 \%) \\
\leftrightarrow: 944(96 \%) \\
\text { n.a.: } 10\end{array}$ & $\begin{array}{l}\uparrow: 15(3 \%) \\
\leftrightarrow: 439(97 \%) \\
\text { n.a.: } 2\end{array}$ & $\begin{array}{l}\uparrow: 23(4 \%) \\
\leftrightarrow: 505(96 \%) \\
\text { n.a.: } 8\end{array}$ & $\begin{array}{l}\text { Wald }=1.771 \\
p=0.183\end{array}$ \\
\hline Protein concentration (Mean $\pm S D$, range) & $\begin{array}{l}471.71 \pm 238.71 \text { (from } \\
107 \text { to } 2890 \mathrm{mg} / \mathrm{l} \text { ) }\end{array}$ & $459.75 \pm 230.92$ & $481.86 \pm 244.89$ & $\begin{array}{l}F=1.079 \\
p=0.299\end{array}$ \\
\hline $\begin{array}{l}\text { Increased protein concentration (ref. < } \\
450 \mathrm{mg} / \mathrm{l})\end{array}$ & $\begin{array}{l}\uparrow: 448 \uparrow(45 \%) \\
\leftrightarrow: 543=(55 \%) \\
\text { n.a.: } 1\end{array}$ & $\begin{array}{l}\uparrow: 201 \uparrow(44 \%) \\
\leftrightarrow: 254=(56 \%) \\
\text { n.a.: } 1\end{array}$ & $\begin{array}{l}\uparrow: 247 \uparrow(46 \%) \\
\leftrightarrow: 289=(54 \%) \\
\text { n.a.: } 0\end{array}$ & $\begin{array}{l}\beta=0.341 \\
\text { Wald }=5.571 \\
\boldsymbol{p}=\mathbf{0 . 0 1 8}\end{array}$ \\
\hline Albumin quotients (Mean \pm SD) & $5.81 \pm 3.18$ & $5.64 \pm 3.18$ & $5.95 \pm 3.19$ & $\begin{array}{l}F=2.682 \\
p=0.102\end{array}$ \\
\hline 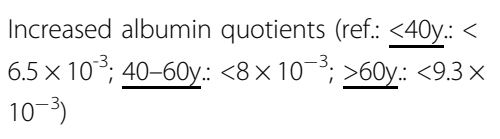 & $\begin{array}{l}\uparrow: 174 \uparrow(18 \%) \\
\leftrightarrow: 815(82 \%) \\
\text { n.a.: } 3\end{array}$ & $\begin{array}{l}\uparrow: 85 \uparrow(19 \%) \\
\leftrightarrow:: 371=(81 \%) \\
\text { n.a.: } 0\end{array}$ & $\begin{array}{l}\uparrow: 89 \uparrow(17 \%) \\
\leftrightarrow: 444=(83 \%) \\
\text { n.a.: } 3\end{array}$ & $\begin{array}{l}\mathrm{Chi}^{2}=0.640 \\
p=0.424\end{array}$ \\
\hline IgG-Index (Mean \pm SD) & $0.50 \pm 0.10$ & $0.51 \pm 0.11$ & $0.50 \pm 0.08$ & $\begin{array}{l}F=0.566 \\
p=0.452\end{array}$ \\
\hline $\begin{array}{l}\text { Number of patients with increased lgG } \\
\text { indices (ref. <0.7) }\end{array}$ & $\begin{array}{l}\uparrow: 19(2 \%) \\
\leftrightarrow: \text { } 970(98 \%) \\
\text { n.a.: } 3\end{array}$ & $\begin{array}{l}\uparrow: 8 \uparrow(2 \%) \\
\leftrightarrow: 448(98 \%) \\
\text { n.a.: } 0\end{array}$ & $\begin{array}{l}\uparrow: 11 \uparrow(2 \%) \\
\leftrightarrow: 522(98 \%) \\
\text { n.a.: } 3\end{array}$ & $\begin{array}{l}\text { Wald }=0.028 \\
p=0.866\end{array}$ \\
\hline Isolated OCB in CSF & $\begin{array}{l}40(4 \%) \\
\text { n.a.: } 26\end{array}$ & $\begin{array}{l}19(4 \%) \\
\text { п.а.: } 7\end{array}$ & $\begin{array}{l}21(4 \%) \\
\text { n.a.: } 19\end{array}$ & $\begin{array}{l}\text { Wald }=0.029 \\
p=0.865\end{array}$ \\
\hline OCBs in CSF and Serum & $\begin{array}{l}52(5 \%) \\
\text { n.a.: } 27\end{array}$ & $\begin{array}{l}20(4 \%) \\
\text { п.а.: } 7\end{array}$ & $\begin{array}{l}32(6 \%) \\
\text { n.a.: } 20\end{array}$ & $\begin{array}{l}\text { Wald }=1.915 \\
p=0.166\end{array}$ \\
\hline OCBs overall & $\begin{array}{l}93(10 \%) \\
\text { n.a.: } 26\end{array}$ & $\begin{array}{l}39(9 \%) \\
\text { n.a.: } 7\end{array}$ & $\begin{array}{l}54(10 \%) \\
\text { n.a.: } 19\end{array}$ & $\begin{array}{l}\text { Wald }=1.084 \\
p=0.298\end{array}$ \\
\hline Cerebrospinal fluid overall variables & & & & \\
\hline Inflammatory CSF changes ${ }^{a}$ & $\begin{array}{l}\text { Yes: 78/992 (8\%) } \\
\text { No: } 914 \text { / } 992(92 \%)\end{array}$ & $\begin{array}{l}34 / 456(7 \%) \\
422 / 456(93 \%)\end{array}$ & $\begin{array}{l}44 / 536(8 \%) \\
492 / 536(92 \%)\end{array}$ & $\begin{array}{l}\text { Wald }=0.198 \\
p=0.656\end{array}$ \\
\hline Overall basic CSF alterations ${ }^{\mathrm{b}}$ & $\begin{array}{l}\text { Yes: 492/992 (50\%) } \\
\text { No: 500/992 (50\%) }\end{array}$ & $\begin{array}{l}222 / 456(49 \%) \\
234 / 456(51 \%)\end{array}$ & $\begin{array}{l}270 / 536(50 \%) \\
266 / 536(50 \%)\end{array}$ & $\begin{array}{l}\beta=0.336 \\
\text { Wald }=5.510 \\
\boldsymbol{p}=\mathbf{0 . 0 1 9}\end{array}$ \\
\hline
\end{tabular}

WBC white blood cell, ref. reference; n.a. not available; OCBs oligoclonal bands, CSF cerebrospinal fluid, SD standard deviation.

anflammatory CSF changes: WBC counts increased and/or IgG indices increased and/or CSF specific oligoclonal bands.

${ }^{b}$ Overall basic CSF alterations: Inflammatory CSF changes and/or increased albumin quotients and/or increased protein concentrations. Abbreviations: WBC, white blood cell; ref., reference; n.a., not available; OCBs, oligoclonal bands, CSF, cerebrospinal fluid; SD, standard deviation.

Significant $p$-values are marked in bold.

well, the detection of serum IgG Abs tended to be more frequent in patients with schizophreniform syndromes. The finding of only a few patients showing questionable CSF Ab positivity is consistent with another study in which 124 patients with schizophreniform psychosis, examined using the same methodology, displayed only negative CSF samples ${ }^{15}$. However, notably, in most of our cases, the serum Ab-positive patients also showed signs of brain involvement in further investigations; indeed, 92\% of the Ab-positive patients showed at least one alteration in CSF, MRI, EEG, or FDG-PET findings. Therefore, our assessment is that all patients with antineuronal $\operatorname{IgG}$ serum Abs should undergo a careful diagnostic workup to verify possible brain involvement. This holds even if the 
Table 5 Autoantibody findings.

\begin{tabular}{|c|c|c|c|c|}
\hline Autoantibody findings & Overall $(N=992)$ & $\begin{array}{l}\text { Schizophreniform syndrome } \\
(N=456)\end{array}$ & $\begin{array}{l}\text { Affective syndrome } \\
(N=536)\end{array}$ & Statistics \\
\hline \multicolumn{5}{|c|}{ IgG anti-thyroid antibodies in SERUM against the following antigens } \\
\hline TPO (reference: $<34 \mathrm{IU} / \mathrm{ml}$ ) & $\begin{array}{l}\uparrow: 72(17 \%), \leftrightarrow: \\
341(83 \%) \\
\text { n.a.: } 579\end{array}$ & $\begin{array}{l}\uparrow: 34(14 \%), \leftrightarrow: 201(86 \%) \\
\text { n.a.: } 221\end{array}$ & $\begin{array}{l}\uparrow: 38(21 \%), \leftrightarrow: 140(79 \%) \\
\text { n.a.: } 358\end{array}$ & $\begin{array}{l}\mathrm{Chi}^{2}=3.331 \\
p=0.068\end{array}$ \\
\hline TG (reference: <115 IU/ml) & $\begin{array}{l}\uparrow: 37(15 \%), \leftrightarrow: \\
210(85 \%) \\
\text { n.a.: } 745\end{array}$ & $\begin{array}{l}\uparrow: 20(13 \%), \leftrightarrow: 129(87 \%) \\
\text { n.a.: } 307\end{array}$ & $\begin{array}{l}\uparrow: 17(17 \%), \leftrightarrow: 81(83 \%) \\
\text { n.a.: } 438\end{array}$ & $\begin{array}{l}\text { Chi }^{2}=0.715 \\
p=0.398\end{array}$ \\
\hline TSHR (reference: $<1.75$ IU/l) & $\begin{array}{l}\uparrow: 11(2 \%), \leftrightarrow: \\
469(98 \%) \\
\text { n.а.: } 512\end{array}$ & $\begin{array}{l}\uparrow: 5(2 \%), \leftrightarrow: 238(98 \%) \\
\text { n.a.: } 213\end{array}$ & $\begin{array}{l}\uparrow: 6(3 \%), \leftrightarrow: 231(97 \%) \\
\text { n.а.: } 299\end{array}$ & $\begin{array}{l}\mathrm{Chi}^{2}=0.120 \\
p=0.729\end{array}$ \\
\hline Anti-thyroid antibodies overall & $\begin{array}{l}\uparrow: 91(17 \%), \leftrightarrow: 439 \\
(83 \%) \\
\text { n.a.: } 462\end{array}$ & $\begin{array}{l}\uparrow: 44(16 \%), \leftrightarrow: 230(84 \%) \\
\text { п.а.: } 182\end{array}$ & $\begin{array}{l}\uparrow: 47(18 \%), \leftrightarrow: 209 \text { (82\%) } \\
\text { п.а.: } 280\end{array}$ & $\begin{array}{l}\text { Chi }^{2}=0.493 \\
p=0.483\end{array}$ \\
\hline
\end{tabular}

Established IgG antineuronal autoantibodies against the following SERUM antigens (Euroimmun ${ }^{\circledR}$ fixed cell assays - screening)

\begin{tabular}{|c|c|c|c|c|}
\hline NMDAR & $\begin{array}{l}++: 1(0.2 \%) \\
+++: 2(0.4 \%)\end{array}$ & $\begin{array}{l}++: 1(0.5 \%) \\
+++: 2(0.9 \%)\end{array}$ & $0(0 \%)$ & - \\
\hline LGl1 & $\begin{array}{l}++: 1(0.2 \%) \\
+++: 1(0.2 \%)\end{array}$ & $++: 1(0.5 \%)$ & $+++: 1(0.4 \%)$ & - \\
\hline CASPR2 & +: $1(0.2 \%)$ & $+: 1(0.5 \%)$ & $0(0 \%)$ & - \\
\hline AMPA-1/2-R, GABA-B-R, DPPX & $0(0 \%)$ & $0(0 \%)$ & $0(0 \%)$ & - \\
\hline \multicolumn{5}{|l|}{ Cell surface antibodies in serum } \\
\hline Questionably positive & $1 / 475(0.2 \%)$ & $1 / 216(0.5 \%)$ & $0 / 259(0 \%)$ & \\
\hline Slightly positive & $2 / 475(0.4 \%)$ & $2 / 216(0.9 \%)$ & $0 / 259(0 \%)$ & \\
\hline Clearly positive & $3 / 475(0.6 \%)$ & $2 / 216(0.9 \%)$ & $1 / 259(0.4 \%)$ & $\mathrm{Chi}^{2}=3.513$ \\
\hline OVERALL & $6 / 475(1 \%)$ & $5 / 216(2 \%)$ & $1 / 259(0.4 \%)$ & $p=0.061$ \\
\hline \multicolumn{5}{|c|}{ Established lgG antineuronal antibodies against the following CSF antigens (Euroimmun ${ }^{\circledR}$ fixed cell assays - screening) } \\
\hline NMDAR & +: $2(0.3 \%)$ & $+: 2(0.6 \%)$ & $0(0 \%)$ & - \\
\hline $\begin{array}{l}\text { AMPA-1/2-R, GABA-B-R, LGI1, } \\
\text { CASPR2, DPPX }\end{array}$ & $0(0 \%)$ & $0(0 \%)$ & $0(0 \%)$ & - \\
\hline Cell surface antibodies in CSF & & & & $\mathrm{Chi}^{2}=2.134$ \\
\hline Questionably positive & $2 / 741(0.3 \%)$ & $2 / 359(0.6 \%)$ & $0 / 382(0 \%)$ & $p=0.144$ \\
\hline
\end{tabular}

Established lgG antineuronal antibodies against the following intracellular antigens in SERUM (Ravo ${ }^{\circledR}$ immunoassay - screening)

$\begin{array}{llll}\text { GAD65 } & +: 2(0.2 \%) & +: 1(0.2 \%) & +: 1(0.2 \%) \\ & +++: 1(0.1 \%) & & +++: 1(0.2 \%) \\ \text { Amphiphysin } & +: 1(0.1 \%) & 0(0 \%) & +: 1(0.2 \%) \\ \text { Hu, Ri, Tr(DNER) } & 0(0 \%) & 0(0 \%) & 0(0 \%) \\ \text { Yo } & +: 7(0.8 \%) & +: 5(1 \%) & +: 2(0.5 \%)^{* *} \\ & +++: 2(0.2 \%) & +++: 2(0.5 \%) & +: 4^{* * * * *}(1 \%) \\ \text { Cv2(CRMP5) } & +: 5(0.6 \%) & +: 1(0.2 \%) & +: 1^{* *}(0.2 \%) \\ \text { HuD } & +: 2(0.2 \%) & +: 1(0.2 \%) & +++: 1^{*}(0.2 \%)\end{array}$


Table 5 continued

\begin{tabular}{|c|c|c|c|c|}
\hline Autoantibody findings & Overall $(N=992)$ & $\begin{array}{l}\text { Schizophreniform syndrome } \\
(N=456)\end{array}$ & $\begin{array}{l}\text { Affective syndrome } \\
(N=536)\end{array}$ & Statistics \\
\hline Ma1/Ma2 & $\begin{array}{l}+(\mathrm{Ma2}): 1(0.1 \%) \\
+++(\mathrm{Ma} 1): 1(0.1 \%)\end{array}$ & $0(0 \%)$ & $\begin{array}{l}+\left(\text { Ma2): } 1(0.2 \%)^{* * * * *}\right. \\
+++(\text { Ma1): } 1(0.2 \%)\end{array}$ & - \\
\hline sox 1 & $\begin{array}{l}+: 17(2 \%) \\
+++: 1(0.1 \%)\end{array}$ & $+: 8(2 \%)^{* * * * *}$ & $\begin{array}{l}+: 9(2 \%)^{* * / * * * / * * * * * * * * *} \\
+++: 1(0.2 \%)^{*}\end{array}$ & - \\
\hline Zic4 & $+: 6(1 \%)$ & $+: 1(0.5 \%)^{* * * * * *}$ & $+: 5(2 \%)^{* *} / * * * / * * * / * * * *$ & - \\
\hline \multicolumn{5}{|l|}{ Intracellular antibodies in serum } \\
\hline Questionably positive & $31 / 826(4 \%)$ & $16 / 405(4 \%)$ & $15 / 421(4 \%)$ & $\begin{array}{l}\mathrm{Chi}^{2}=0.086 \\
p=0.769\end{array}$ \\
\hline Clearly positive & $5 / 826(0.6 \%)$ & $2 / 405(0.5 \%)$ & $3 / 421(0.7 \%)$ & $\begin{array}{l}\mathrm{Chi}^{2}=0.164 \\
p=0.685\end{array}$ \\
\hline \multicolumn{5}{|c|}{ IgG SERUM antibodies associated with demyelinating diseases (Euroimmun ${ }^{\circledR}$ fixed cell assays) } \\
\hline AGP4 & $0(0 \%)$ & $0(0 \%)$ & $0(0 \%)$ & - \\
\hline MOG & $+++: 1(1 \%)$ & $+++: 1(1 \%)$ & $0(0 \%)$ & $\begin{array}{l}\mathrm{Chi}^{2}=0.528 \\
p=0.468\end{array}$ \\
\hline \multicolumn{5}{|c|}{ Antibody findings in tissue tests (indirect immune-fluorescence on unfixed murine brain tissue: Prof. Prüss, Berlin, Germany) } \\
\hline In Serum overall & $7(23 \%)$ & $5(31 \%)$ & $2(14 \%)$ & - \\
\hline Anti-granule cell pattern & $4(13 \%)$ & $3(19 \%)$ & $1(7 \%)$ & \\
\hline Anti-vessel pattern & $2(7 \%)$ & $1(6 \%)$ & $1(7 \%)$ & \\
\hline Anti-myelin pattern & $1(3 \%)$ & $1(6 \%)$ & $0(0 \%)$ & \\
\hline In CSF overall & $8(27 \%)$ & $6(38 \%)$ & $2(14 \%)$ & \\
\hline Anti-granule cell pattern & $4(13 \%)$ & $3(19 \%)$ & $1(7 \%)$ & \\
\hline Anti-vessel pattern & $3(10 \%)$ & $2(13 \%)$ & $1(7 \%)$ & - \\
\hline Anti-myelin pattern & $1(3 \%)$ & $1(6 \%)$ & $0(0 \%)$ & \\
\hline $\begin{array}{l}\text { Positive tissue tests in serum and/or CSF } \\
\text { OVERALL }\end{array}$ & $9 / 30(30 \%)$ & $7 / 16(44 \%)$ & $2 / 14(14 \%)$ & $\begin{array}{l}\mathrm{Chi}^{2}=3.087 \\
p=0.079\end{array}$ \\
\hline
\end{tabular}

+ : Questionably positive, ++ : Slightly positive, +++ : Clearly positive.

*One patient had two +++ antibody findings: HuD and SOX1.

**One patient had multiple + antibody findings: Zic4, Sox1, Yo, CV2, and HuD.

${ }^{* * *}$ One patient had multiple + antibody findings: Zic4, Sox1, CV2(CRMP5).

****One patient with two slightly positive antibody findings: anti-SoX1 and Zic4.

*****One patient had multiple + antibody findings: anti-Zic4, Sox1, and Ma2.

******one patient had two + antibody findings: Sox1 and Zic4.

The overall alterations are marked in bold.

patients are CSF Ab negative, since isolated serum Abs can still have therapeutic consequences ${ }^{38}$. According to current international consensus criteria, the detection of antineuronal $\mathrm{Abs}$ in the serum, in combination with typical EEG or CSF alterations, is indicative of a "probable AP" 2 .

The role of tissue tests in selected clinical cases is also worth noting and was clinically relevant in several cases. Tissue tests analyzing serum and CSF were frequently conspicuous in patients with red flags for AP. Experiences with some patients have already been published ${ }^{9,39,40}$. Besides granule cell patterns, Abs against vascular structures were found, most likely directed against endothelial cells. The significance and specificity of these findings is not yet clear, as data on the prevalence of these findings in healthy controls is lacking. Similar findings were recently described in association with neuromyelitis opticum (NMO) spectrum diseases ${ }^{41}$. Pathophysiologically, Abs directed against endothelial cells might lead to a BBB dysfunction. In this context, different pathophysiological mechanisms could contribute secondarily to the development of psychiatric syndromes ${ }^{35}$. In addition, Abs against myelin structures were found. These findings are interesting in light of the constantly expanding range of NMO spectrum diseases ${ }^{42}$ and their previously described association with psychotic and affective symptoms ${ }^{43,44}$. In 
Table 6 Instrument-based diagnostics.

\begin{tabular}{|c|c|c|c|c|}
\hline & Total $(N=992)$ & $\begin{array}{l}\text { Schizophreniform syndrome } \\
(N=456)\end{array}$ & $\begin{array}{l}\text { Affective syndrome } \\
(N=536)\end{array}$ & Statistics \\
\hline EEG & $N=954(96 \%)$ & $N=449(98 \%)$ & $N=505(94 \%)$ & \\
\hline \multicolumn{5}{|l|}{ Visual assessment } \\
\hline Continuous generalized slow activity & $34(4 \%)$ & $19(4 \%)$ & $15(3 \%)$ & - \\
\hline Continuous regional slow activity & $6(0.6 \%)$ & $5(1 \%)$ & $1(0.2 \%)$ & - \\
\hline Intermittent generalized slow activity & $162(17 \%)$ & $103(23 \%)$ & $59(12 \%)$ & - \\
\hline Intermittent regional slow activity & $53(6 \%)$ & $25(6 \%)$ & $28(6 \%)$ & - \\
\hline Epileptic pattern & $29(3 \%)$ & $23(5 \%)$ & $6(1 \%)$ & - \\
\hline EEG overall alterations & $242 / 954(25 \%)$ & 142/449 (32\%) & 100/505 (20\%) & $\begin{array}{l}\beta=0.709 \\
\text { Wald }=18.485 \\
\boldsymbol{p}<\mathbf{0 . 0 0 1}\end{array}$ \\
\hline \multicolumn{5}{|l|}{ Automatic IRDAVIRTA quantification (mean values per minute) } \\
\hline & & $N=445(99 \%)$ & $N=501(99 \%)$ & \\
\hline IRDA/IRTA rate before hyperventilation & $1.73 \pm 2.36$ & $1.88 \pm 2.56$ & $1.60 \pm 2.16$ & $\begin{array}{l}F=0.323 \\
p=0.570\end{array}$ \\
\hline IRDA/IRTA rate after hyperventilation ( $N=803,85 \%)$ & $2.71 \pm 3.98$ & $3.04 \pm 4.41(N=396)$ & $2.39 \pm 3.48(N=407)$ & $\begin{array}{l}F=3.182 \\
p=0.075\end{array}$ \\
\hline $\begin{array}{l}\text { Difference in IRDA/IRTA rates before and after } \\
\text { hyperventilation }(\mathrm{N}=803,85 \%)\end{array}$ & $0.86 \pm 3.08$ & $1.09 \pm 3.32(\mathrm{~N}=396)$ & $0.63 \pm 2.81(N=407)$ & $\begin{array}{l}F=3.398 \\
p=0.066\end{array}$ \\
\hline IRDA/IRTA rate overall & $1.90 \pm 2.50$ & $2.13 \pm 2.80$ & $1.70 \pm 2.17$ & $\begin{array}{l}F=1.460 \\
p=0.227\end{array}$ \\
\hline MRI & $N=896(90 \%)$ & $N=418(92 \%)$ & $N=478(89 \%)$ & \\
\hline \multicolumn{5}{|l|}{ Visual assessment } \\
\hline White/Gray matter changes overall ${ }^{a}$ & $461(51 \%)$ & $172(41 \%)$ & $289(60 \%)$ & $\begin{array}{l}\text { Wald }=1.148 \\
p=0.284\end{array}$ \\
\hline Non-specific white matter changes & $375(42 \%)$ & $145(35 \%)$ & $230(48 \%)$ & $\begin{array}{l}\text { Wald }=0.347 \\
p=0.556\end{array}$ \\
\hline $\begin{array}{l}\text { Gray matter changes of amygdalae, hippocampi, other } \\
\text { limbic structures }\end{array}$ & $12(1 \%)$ & $3(1 \%)$ & $9(2 \%)$ & $\begin{array}{l}\text { Wald }=0.871 \\
p=0.351\end{array}$ \\
\hline Lesions/alterations & $6(0.7 \%)$ & $3(1 \%)$ & $3(0.6 \%)$ & \\
\hline Atrophy & $5(0.6 \%)$ & $0(0 \%)$ & $5(1 \%)$ & \\
\hline Sclerosis & $2(0.2 \%)$ & $0(0 \%)$ & $2(0.4 \%)$ & \\
\hline $\begin{array}{l}\text { Possible/probable/ definite (post-) inflammatory } \\
\text { changes }\end{array}$ & $77(9 \%)$ & $23(6 \%)$ & $54(11 \%)$ & $\begin{array}{l}\beta=0.742 \\
\text { Wald }=7.218 \\
\boldsymbol{p}=\mathbf{0 . 0 0 7}\end{array}$ \\
\hline Atrophic changes overall & $108(12 \%)$ & $32(8 \%)$ & $76(16 \%)$ & $\begin{array}{l}\text { Wald }=0.116 \\
p=0.733\end{array}$ \\
\hline Generalized cortical atrophy & $34(4 \%)$ & $9(2 \%)$ & $25(5 \%)$ & $\begin{array}{l}\text { Wald }=0.918 \\
p=0.338\end{array}$ \\
\hline Localized atrophy & $52(6 \%)$ & $16(4 \%)$ & $36(8 \%)$ & $\begin{array}{l}\text { Wald }=0.033 \\
p=0.855\end{array}$ \\
\hline Ventricle enlargement & $37(4 \%)$ & $14(3 \%)$ & $23(5 \%)$ & $\begin{array}{l}\text { Wald }=0.492 \\
p=0.483\end{array}$ \\
\hline $\begin{array}{l}\text { Macroangiopathic vascular alterations (post-ischemic } \\
\text { changes) }\end{array}$ & $33(4 \%)$ & $7(2 \%)$ & $26(5 \%)$ & $\begin{array}{l}\text { Wald }=0.388 \\
p=0.533\end{array}$ \\
\hline Microhaemorrhage & $17(2 \%)$ & $3(0.7 \%)$ & $14(3 \%)$ & $\begin{array}{l}\text { Wald }=1.109 \\
p=0.292\end{array}$ \\
\hline \multicolumn{5}{|l|}{ Cysts, tumors, anatomical variants and other changes } \\
\hline Cysts & $119(15 \%)$ & $63(15 \%)$ & $56(12 \%)$ & $\begin{array}{l}\text { Wald }=0.210 \\
p=0.647\end{array}$ \\
\hline Pineal cyst & $67(7 \%)$ & $38(9 \%)$ & $29(6 \%)$ & \\
\hline Arachnoid cyst & $28(3 \%)$ & $12(3 \%)$ & $16(3 \%)$ & \\
\hline Fissura choroidea cyst & $9(0.7 \%)$ & $3(0.7 \%)$ & $6(1 \%)$ & \\
\hline Others $^{c}$ & $25(3 \%)$ & $13(3 \%)$ & $12(3 \%)$ & \\
\hline Tumors & $13(1 \%)$ & $4(1 \%)$ & $9(2 \%)$ & $\begin{array}{l}\text { Wald }=0.181 \\
p=0.671\end{array}$ \\
\hline Meningioma & $7(0.8 \%)$ & $2(0.5 \%)$ & $5(1 \%)$ & \\
\hline Cavernoma & $5(0.6 \%)$ & $2(0.5 \%)$ & $3(0.6 \%)$ & \\
\hline Acusticus neurinoma & $1(0.1 \%)$ & $0(0 \%)$ & $1(0.2 \%)$ & \\
\hline Pituitary adenoma & $3(0.3 \%)$ & $2(0.5 \%)$ & $1(0.2 \%)$ & \\
\hline
\end{tabular}


Table 6 continued

\begin{tabular}{|c|c|c|c|c|}
\hline & Total $(N=992)$ & $\begin{array}{l}\text { Schizophreniform syndrome } \\
(N=456)\end{array}$ & $\begin{array}{l}\text { Affective syndrome } \\
(N=536)\end{array}$ & Statistics \\
\hline Anatomical variants and other changes & $209(23 \%)$ & $107(26 \%)$ & $102(21 \%)$ & $\begin{array}{l}\text { Wald }=1.750 \\
p=0.186\end{array}$ \\
\hline DVA & $37(4 \%)$ & $20(5 \%)$ & $17(4 \%)$ & \\
\hline Hippocampal malrotation & $3(0.3 \%)$ & $2(0.5 \%)$ & $1(0.2 \%)$ & \\
\hline Falx metaplasia & $2(0.2 \%)$ & $2(0.5 \%)$ & $0(0 \%)$ & \\
\hline Others $^{d}$ & $8(0.9 \%)$ & $5(1 \%)$ & $3(0.6 \%)$ & \\
\hline \multicolumn{5}{|l|}{ Ventricle changes } \\
\hline Asymmetries & $57(6 \%)$ & $31(7 \%)$ & $26(5 \%)$ & \\
\hline NPH aspect & $10(1 \%)$ & $1(0.2 \%)$ & $9(2 \%)$ & \\
\hline Malformations ${ }^{\mathrm{e}}$ & $5(0.6 \%)$ & $2(0.5 \%)$ & $3(0.6 \%)$ & \\
\hline Perivascular space enlargement & $16(2 \%)$ & $8(2 \%)$ & $8(2 \%)$ & \\
\hline Virchow-Robin's space enlargement & $39(4 \%)$ & $13(3 \%)$ & $26(5 \%)$ & \\
\hline Subarachnoid space enlargement & $18(2 \%)$ & $9(2 \%)$ & $9(2 \%)$ & \\
\hline Megacisterna magna & $6(0.7 \%)$ & $5(1 \%)$ & $1(0.2 \%)$ & \\
\hline Gliosis of unclear origin & $4(0.4 \%)$ & $1(0.2 \%)$ & $3(0.6 \%)$ & \\
\hline Others $^{f}$ & $23(3 \%)$ & $13(3 \%)$ & $10(2 \%)$ & \\
\hline Overall MRI changes & $641(72 \%)$ & $273(65 \%)$ & 368 (77\%) & $\begin{array}{l}\text { Wald }=0.031 \\
p=0.861\end{array}$ \\
\hline
\end{tabular}

Several EEG and MRI changes were noted, if existing.

EEG electroencephalography, IRDA/IRTA intermittent rhythmic generalized delta/theta activity, MRI magnetic resonance imaging.

${ }^{a}$ White/gray matter changes overall: non-specific white matter changes and/or gray matter changes of amygdalae, hippocampi, other limbic structures and/or (post-) inflammatory changes.

${ }^{\mathrm{b}}$ Atrophic changes overall: generalized cortical atrophy and/or localized atrophy and/or ventricle enlargement.

${ }^{c}$ Neuroepithelial cyst $(N=1)$, neuroglial cyst $(N=1)$, plexus cysts $(N=4)$, hypophysis cysts $(N=6)$, thalamus cyst $(N=1)$, hygromae $(N=4)$, unspecified cysts $(N=8)$, dVascular anomalies $(N=4)$, additional sulci $(N=3)$, heteropia $(N=1)$.

e Focal cortical dysplasia $(N=2)$, arteriovenous malformation $(N=1)$, hamartoma $(N=1)$, schizencephaly $(N=1)$.

${ }^{f}$ Thalamus lesion $(N=2)$, hypophysis alterations $(N=12)$, cerebellar hypoplasia $(N=1)$, cerebellar lesion $(N=1)$ others $(N=3)$. Abbreviations: EEG, electroencephalography, IRDA/IRTA, intermittent rhythmic generalized delta/theta activity; MRI, magnetic resonance imaging.

Significant $p$-values are marked in bold.

summary, our opinion is that novel Abs against so far unknown antigens could play a decisive role in a subgroup of patients with severe mental disorders.

A major limitation of the present study is its retrospective, open, and uncontrolled design, which meant that many patients did not receive all tests. For example, the measurement of established antineuronal Abs against cell surface antigens was not introduced until 2011 in our department. Initially, these Abs were only tested in the CSF, as CSF testing was considered more sensitive for the detection of anti-NMDAR encephalitis ${ }^{45}$. Our own observations revealed that anti-NMDAR encephalitis can probably also occur in patients with isolated positive serum results ${ }^{38}$, so serum analyses were introduced later, in addition to CSF analysis. The retrospective approach of the study also meant that confirmatory test results for the positive $\mathrm{Ab}$ findings from other investigators or with other methods or in other laboratories were not routinely performed. In some cases, the questionable Ab-positive cases could not be confirmed externally (e.g., for patient 1 in Table 7), while other findings (e.g., for patient 9 in Table 7) were only slightly positive. However, this is precisely the situation encountered by clinicians in their everyday lives. In the psychiatric setting, weakly positive $\mathrm{Ab}$ findings or $\mathrm{Ab}$ titers below the current detection threshold of the standard assays could also be relevant. For example, a possibly long-lasting but milder antibody effect on the brain, occurring via processes such as synaptic reconstruction, could lead to subtler psychiatric phenotypes. For this reason, we have openly described all findings, including questionable results and those from external laboratories/follow-up tests, and the additional findings for these patients are summarized in Table 7 . Some patients showed constellations of an AP/AE (e.g., case 2 in Table 7), whereas several other cases had assessments that remained more nebulous (e.g., in case 5 in Table 7). In our department, the use of tissue tests was not fully established until the end of 2018. Nevertheless, even now, this very laborious examination remains reserved for selected cases with high suspicion of $\mathrm{AP}^{9,39,40}$. The open design, the broad inclusion criteria (e.g., not excluding patients with different comorbidities), and the fact that a tertiary referral center would obviously attract patients for organic differential diagnosis could have led to a distortion of the results. Similarly, the use of an uncontrolled design precluded estimation of the prevalence of CSF alterations and positive tissue tests in healthy individuals. However, comparative values are available from neurological control groups. For example, an increased $A Q$ in patients with retrobulbar neuritis was 


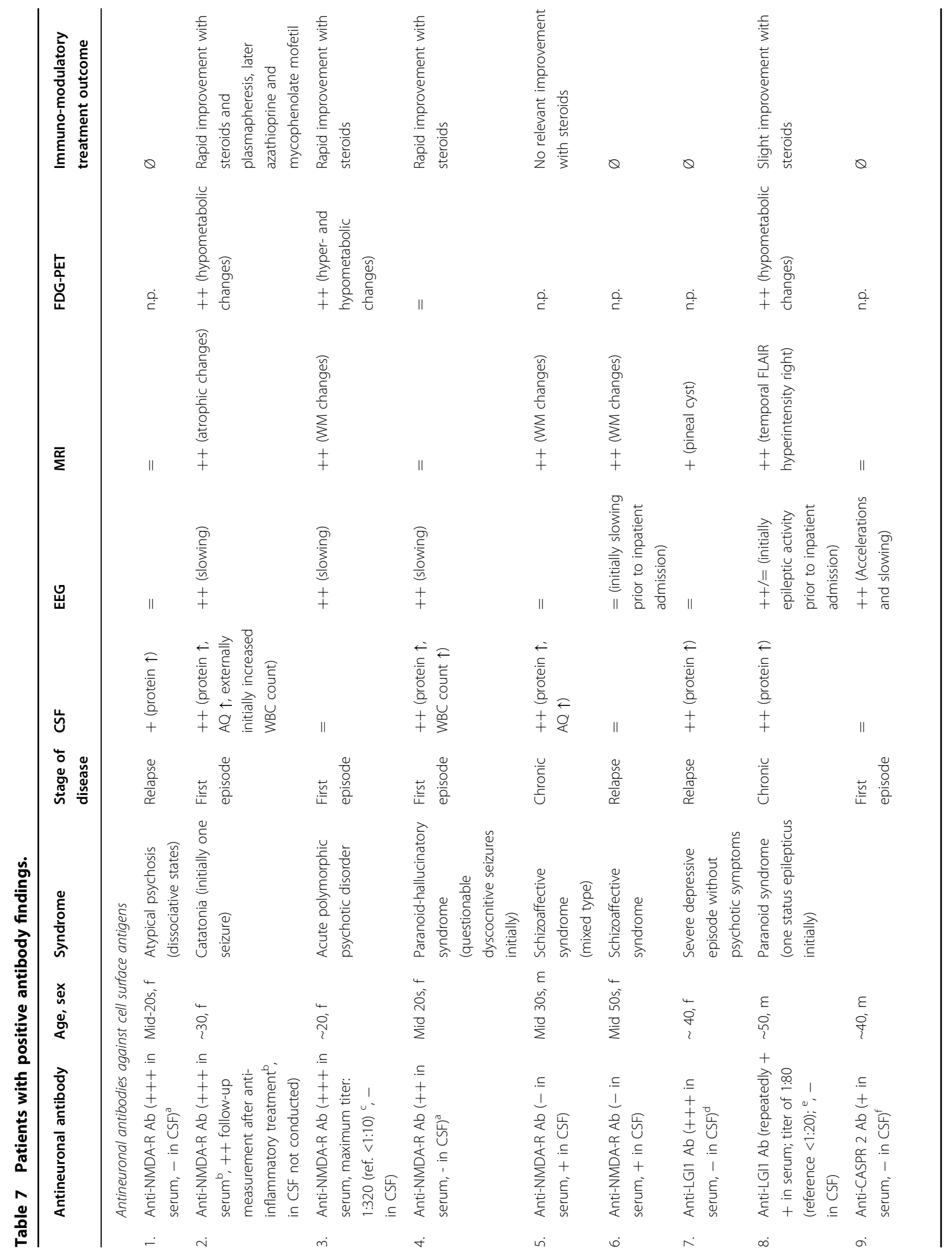




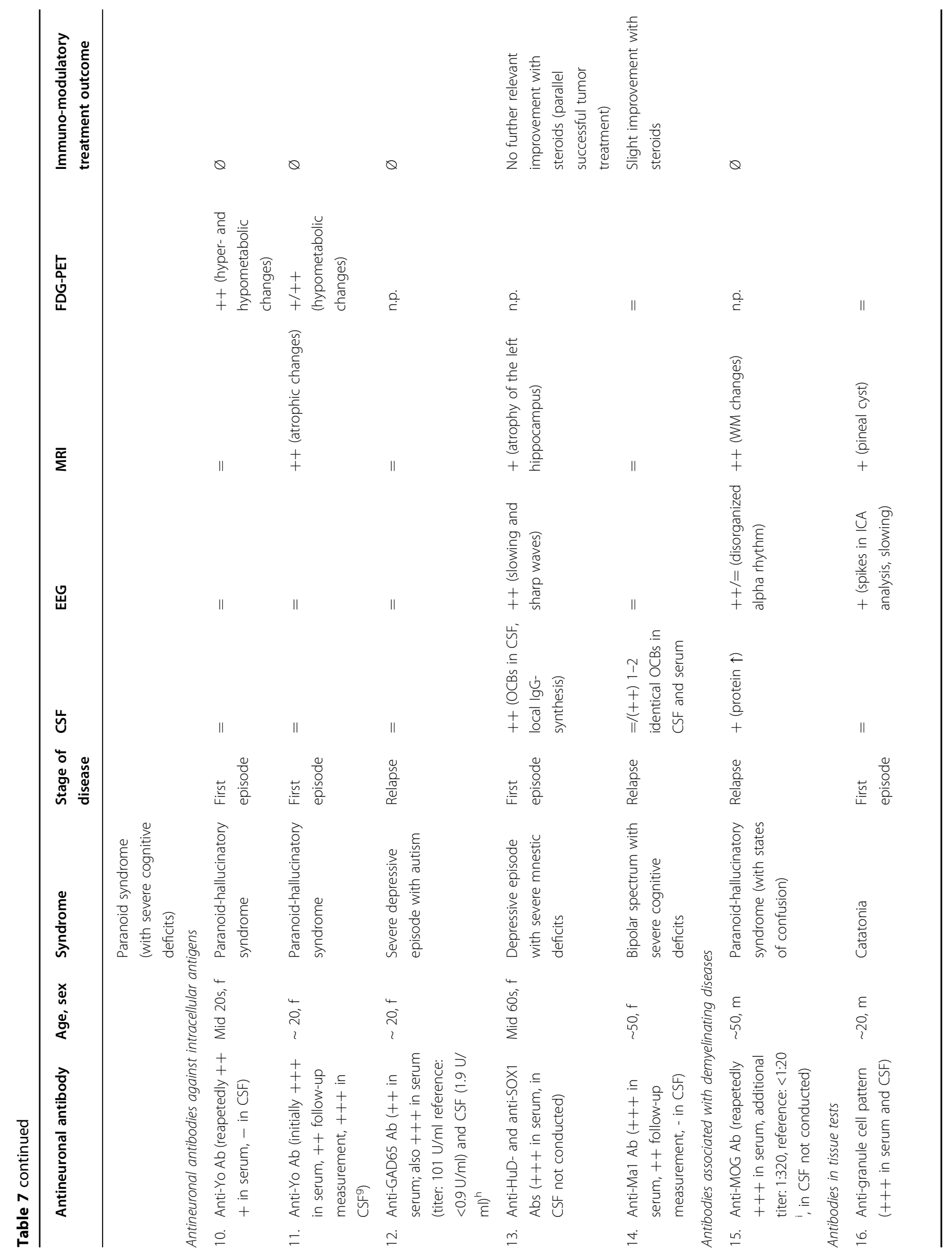




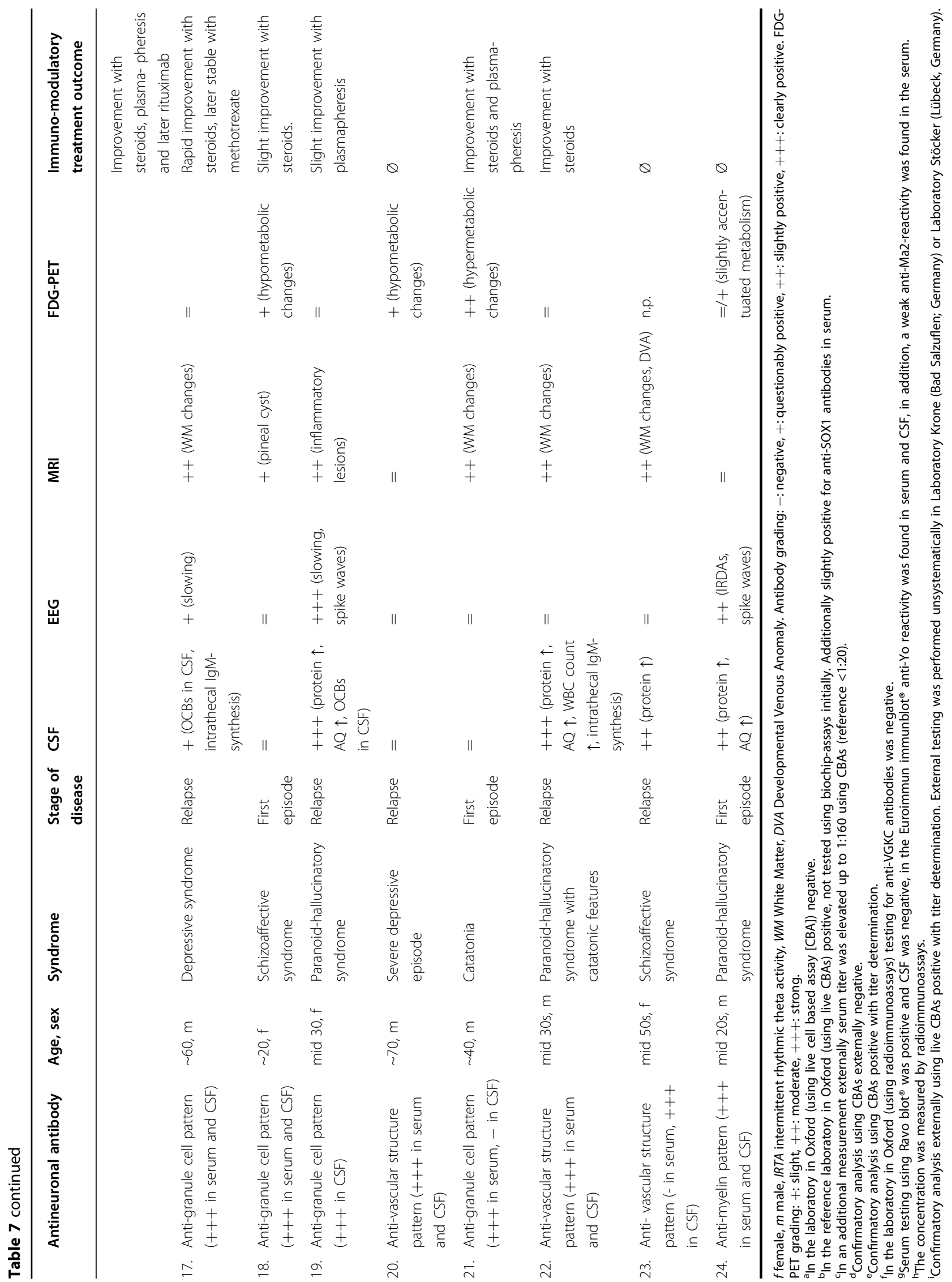


found in only $3.8 \%{ }^{46}$, whereas the authors detected significantly higher percentages (18\%) in similarly aged patients with schizophreniform syndromes. Three subgroups of the patients presented here have already been described in the previous studies ${ }^{14,23,24}$. Multimodal prospective screening studies combining all available methods are desirable in future, especially since the sensitivity of different antineuronal Ab test methods differs significantly ${ }^{47}$. These variations in sensitivity may also explain the low $\mathrm{Ab}$ prevalence observed in the present study. Unlike some previous large studies analyzing the serum antineuronal Ab prevalence ${ }^{11,12}$, the present study was focused only on IgG Abs that are clearly associated with an $\mathrm{AE}^{48}$.

\section{Conclusions}

CSF findings often revealed a dysfunction of the BBB and, less frequently, signs of neuroinflammation. Established high-level antineuronal Abs in serum were rare, and they occurred even less frequently in the CSF. However, several serum-only Ab-positive patients showed evidence of brain involvement in instrument-based clinical studies. Surprisingly, the use of screening tissue tests frequently detected pathologies in pre-selected patients. Novel antineuronal Abs with so far unknown antigens could, therefore, play a decisive role in psychiatry. Further multimodal, prospective, and controlled studies are necessary.

\section{Acknowledgements}

D.E. was funded by the Berta-Ottenstein-Programme for Advanced Clinician Scientists, Faculty of Medicine, University of Freiburg. The article processing charge was funded by the University of Freiburg in the funding program Open Access Publishing. Open Access funding enabled and organized by Projekt DEAL.

\section{Author details \\ ${ }^{1}$ Section for Experimental Neuropsychiatry, Department of Psychiatry and Psychotherapy, Medical Center - University of Freiburg, Faculty of Medicine, University of Freiburg, 79104 Freiburg, Germany. ${ }^{2}$ Department of Psychiatry and Psychotherapy, Medical Center - University of Freiburg, Faculty of Medicine, University of Freiburg, 79104 Freiburg, Germany. ${ }^{3}$ Clinic of Neurology and Neurophysiology, Medical Center - University of Freiburg, Faculty of Medicine, University of Freiburg, 79106 Freiburg, Germany. ${ }^{4}$ Medical Care Center, Neurology, 78464 Konstanz, Germany. ${ }^{5}$ Department of Rheumatology and Clinical Immunology, Medical Center - University of Freiburg, Faculty of Medicine, University of Freiburg, 79106 Freiburg, Germany. ${ }^{6}$ Department of Neuroradiology, Medical Center - University of Freiburg, Faculty of Medicine, University of Freiburg, 79106 Freiburg, Germany. ${ }^{7}$ Center for Basics in Neuromodulation, Faculty of Medicine, University of Freiburg, 79106 Freiburg, Germany. ${ }^{8}$ Department of Neurology and Experimental Neurology, Charité - Universitätsmedizin Berlin, 10117 Berlin, Germany. ${ }^{9}$ German Center for Neurodegenerative Diseases (DZNE) Berlin, 10117 Berlin, Germany}

\section{Author contributions}

D.E. and L.T.V.E. established the screening approach. S.M. and M.Ma. performed the data search. D.E. and S.M. created the results section. B.F. and S.J.M. supervised the statistical analyses. D.E. and S.M. wrote the paper. B.F. performed and interpreted the automated EEG analyses. R.D. and O.S. performed the CSF basic analyses and antineuronal antibody testing and supported the interpretation of these findings. N.V. performed the immunological interpretation. H.P. performed and interpreted the tissue tests. K.R., K.N., S.J.M., M.Mi., and K.D. supported the clinical interpretation and critically revised the paper. H.U. was responsible for MRI analyses and interpretation. All authors were critically involved in the theoretical discussion and composition of the paper. All authors read and approved the final version of the paper.

\section{Conflict of interest}

D.E.: None. S.M.: None. B.F.: None. R.D.: Lecture fees from Roche and travel grants from Biogen. O.S.: None. N.V.: Advisory boards, lectures, and travel grants from Roche. S.M.: None. M.Ma.: None. M.Mi.: None. K.R.: None. K.N.: None. H.U.: Shareholder of the Veobrain: K.D.: Steering Committee Neurosciences, Janssen. H.P.: None. L.T.v.E.: Advisory boards, lectures, or travel grants within the last three years: Roche, Eli Lilly, Janssen-Cilag, Novartis, Shire, UCB, GSK, Servier, Janssen, and Cyberonics.

\section{Publisher's note}

Springer Nature remains neutral with regard to jurisdictional claims in published maps and institutional affiliations.

Received: 25 April 2020 Revised: 12 July 2020 Accepted: 22 July 2020

Published online: 12 August 2020

\section{References}

1. Graus, F. et al. A clinical approach to diagnosis of autoimmune encephalitis. Lancet Neurol. 15, 391-404 (2016).

2. Pollak, T. A. et al. Autoimmune psychosis: an international consensus on an approach to the diagnosis and management of psychosis of suspected autoimmune origin. Lancet Psychiatry 7, 93-108 (2020).

3. Stich, O. \& Rauer, S. [Paraneoplastic neurological syndromes and autoimmune encephalitis]. Nervenarzt 85, 485-498 (2014). quiz 499-501.

4. Dalmau, J. et al. An update on anti-NMDA receptor encephalitis for neurologists and psychiatrists: mechanisms and models. Lancet Neurol. 18, 1045-1057 (2019).

5. Dalmau, J. et al. Anti-NMDA-receptor encephalitis: case series and analysis of the effects of antibodies. Lancet Neurol. 7, 1091-1098 (2008).

6. Endres, D. et al. [Autoantibody-associated schizophreniform psychoses: clinical symptomatology]. Nervenarzt. 90, 547-563 (2019).

7. Tebartz van Elst, L. et al. [Autoantibody-associated schizophreniform psychoses: pathophysiology, diagnostics, and treatment]. Nervenarzt. 90, 745-761 (2019).

8. Dalmau, J. \& Graus, F. Antibody-mediated encephalitis. N. Engl. J. Med. 378, 840-851, https://doi.org/10.1056/NEJMra1708712 (2018).

9. Endres D., et al. Probable autoimmune catatonia with antibodies against cilia on hippocampal granule cells and highly suspicious cerebral FDG-PET findings. Biol. Psychiatry. 87, e29-e31 (2020).

10. Kreye, J. et al. Human cerebrospinal fluid monoclonal N-methyl-D-aspartate receptor autoantibodies are sufficient for encephalitis pathogenesis. Brain 139, 2641-2652 (2016).

11. Dahm, L. et al. Seroprevalence of autoantibodies against brain antigens in health and disease. Ann. Neurol. 76, 82-94 (2014).

12. Hammer, C. et al. Neuropsychiatric disease relevance of circulating anti-NMDA receptor autoantibodies depends on blood-brain barrier integrity. Mol. Psychiatry 19, 1143-1149 (2014).

13. Lennox, B. R. et al. Prevalence and clinical characteristics of serum neuronal cell surface antibodies in first-episode psychosis: a case-control study. Lancet Psychiatry 4, 42-48 (2017).

14. Endres, D. et al. Immunological findings in psychotic syndromes: a tertiary care hospital's CSF sample of 180 patients. Front Hum. Neurosci. 9, 476 (2015).

15. Oviedo-Salcedo, T. et al. Absence of cerebrospinal fluid antineuronal antibodies in schizophrenia spectrum disorders. Br. J. Psychiatry. 212, 318-320 (2018).

16. Blinder, T. \& Lewerenz, J. Cerebrospinal fluid findings in patients with autoimmune encephalitis—a systematic analysis. Front Neurol. 10, 804 (2019). 
17. Endres, D. et al. Hypoglutamatergic state is associated with reduced cerebral glucose metabolism in anti-NMDA receptor encephalitis: a case report. BMC Psychiatry 15, 186 (2015)

18. van Elst, L. T., Klöppel, S. \& Rauer, S. Voltage-gated potassium channel/LGl1 antibody-associated encephalopathy may cause brief psychotic disorder. J. Clin. Psychiatry 72, 722-723 (2011).

19. Rush, A. J. Handbook of Psychiatric Measures, 1st ed. American Psychiatric Association, Washington, DC (2000).

20. American Psychiatric Association. Diagnostic and Statistical Manual of Mental Disorders: DSM-IV-TR. 4th ed. Arlington, VA (2009).

21. Arbeitsgemeinschaft für Methodik und Dokumentation in der Psychiatrie. Das AMDP-System: Manual zur Dokumentation psychiatrischer Befunde. 10th ed. Hogrefe, Göttingen (2018).

22. Engelborghs, S. et al. Consensus guidelines for lumbar puncture in patients with neurological diseases. Alzheimers Dement (Amst.). 8, 111-126 (2017).

23. Endres, D. et al. Alterations in cerebrospinal fluid in patients with bipolar syndromes. Front Psychiatry 7, 194 (2016).

24. Endres, D. et al. Evidence of cerebrospinal fluid abnormalities in patients with depressive syndromes. J. Affect Disord. 198, 178-184 (2016).

25. Hottenrott, $T$. et al. The MRZ reaction and a quantitative intrathecal lgG synthesis may be helpful to differentiate between primary central nervous system lymphoma and multiple sclerosis. J. Neurol. 265, 1106-1114 (2018).

26. Stich, O. et al. An observational study of inflammation in the central nervous system in patients with bipolar disorder. Bipolar Disord. 17, 291-302 (2015).

27. Herken, J. \& Prüss, H. Red flags: clinical signs for identifying autoimmune encephalitis in psychiatric patients. Front Psychiatry 8, 25 (2017).

28. Schumacher, H. et al. IgA autoantibodies against native myelin basic protein in a patient with MS. Neurol. Neuroimmunol. Neuroinflamm. 6, e569 (2019).

29. Endres, D. et al. Increased rates of intermittent rhythmic delta and theta activity in the electroencephalographies of adult patients with attentiondeficit hyperactivity disorder. Epilepsy Behav. 75, 60-65 (2017).

30. Endres, D. et al. Altered intermittent rhythmic delta and theta activity in the electroencephalographies of high functioning adult patients with autism spectrum disorder. Front Hum. Neurosci. 11, 66 (2017).

31. Orlovska-Waast, S. et al. Cerebrospinal fluid markers of inflammation and infections in schizophrenia and affective disorders: a systematic review and meta-analysis. Mol. Psychiatry 24, 869-887 (2019).

32. Bauer, K. \& Kornhuber, J. Blood-cerebrospinal fluid barrier in schizophrenic patients. Eur. Arch. Psychiatry Neurol. Sci. 236, 257-259 (1987).

33. Pitts, A. F., Carroll, B. T., Gehris, T. L., Kathol, R. G. \& Samuelson, S. D. Elevated CSF protein in male patients with depression. Biol. Psychiatry 28, 629-637 (1990).
34. Zetterberg, $\mathrm{H}$. et al. Blood-cerebrospinal fluid barrier dysfunction in patients with bipolar disorder in relation to antipsychotic treatment. Psychiatry Res. 217 143-146 (2014).

35. Naijar, S. et al. Neurovascular unit dysfunction and blood-brain barrier hyperpermeability contribute to schizophrenia neurobiology: a theoretical integration of clinical and experimental evidence. Front Psychiatry 8, 83 (2017).

36. Ehrenreich, H. Autoantibodies against the $\mathrm{N}$-methyl-d-aspartate receptor subunit NR1: untangling apparent inconsistencies for clinical practice. Front Immunol. 8, 181 (2017).

37. Vasic, N., Connemann, B. J., Wolf, R. C., Tumani, H. \& Brettschneider, J. Cerebrospinal fluid biomarker candidates of schizophrenia: where do we stand? Eur. Arch. Psychiatry Clin. Neurosci. 262, 375-391 (2012).

38. Endres, D. et al. Psychiatric presentation of anti-NMDA receptor encephalitis. Front Neurol. 10, 1086 (2019).

39. Endres D., et al. Probable autoimmune depression in a patient with multiple sclerosis and antineuronal antibodies. Front Psychiatry 11, 745 (2020).

40. Endres D., et al. Novel antineuronal autoantibodies with somatodendritic staining pattern in a patient with autoimmune psychosis. Front Psychiatry 11, 627 (2020).

41. Shimizu, F. et al. GRP 78 antibodies are associated with clinical phenotype in neuromyelitis optica. Ann. Clin. Transl. Neurol. 6, 2079-2087 (2019).

42. Jarius, S. et al. [MOG encephalomyelitis: international recommendations on diagnosis and antibody testing]. Nervenarzt 89, 1388-1399 (2018).

43. Bejerot, S. et al. Neuromyelitis optica spectrum disorder with increased aquaporin-4 microparticles prior to autoantibodies in cerebrospinal fluid: a case report. J. Med Case Rep. 13, 27 (2019).

44. Iorio, R. Treatment-resistant depression and aquaporin-4 autoantibodies: is there a link? Biol. Psychiatry 78, e1-e2 (2015).

45. Gresa-Arribas, N. et al. Antibody titres at diagnosis and during follow-up of anti-NMDA receptor encephalitis: a retrospective study. Lancet Neurol. 13 167-177 (2014)

46. Brettschneider, J., Claus, A., Kassubek, J. \& Tumani, H. Isolated bloodcerebrospinal fluid barrier dysfunction: prevalence and associated diseases. J. Neurol. 252, 1067-1073 (2005)

47. Jézéquel, J. et al. Cell- and single molecule-based methods to detect anti-N-methyl-D-aspartate receptor autoantibodies in patients with firstepisode psychosis from the OPTiMiSE project. Biol. Psychiatry $\mathbf{8 2}$ 766-772 (2017).

48. Hara, M. et al. Clinical and pathogenic significance of $\lg G, \lg A$, and $\lg M$ antibodies against the NMDA receptor. Neurology 90, e1386-e1394 (2018). 